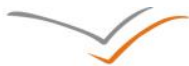

\title{
VERSITA
}

\section{Performance Analysis and Benchmarking of Commercial Banks Operating in Bosnia and Herzegovina: a DEA Approach}

\section{Deni Memić}

Sarajevo School of Science and Technolocy, Economics Department, Sarajevo, Bosnia and Herzegovina \& Hypo Alpe Adria Bank d.d. Mostar, Bosnia and Herzegovina.

\section{Selma Škaljić-Memić}

Centralna Banka Bosne i Hercegovine, Sarajevo, Bosnia and Herzegovina

\section{Abstract}

Background: During the last four years, the banking sector in Bosnia and Herzegovina has been facing crisis which has caused the stagnation within the sector. Still, the results within the sector vary to a great extent from bank to bank. Objectives: The efficiency score is assessed for each bank and serves as a basis for further comparisons between banks in the period between 2008 and 2010. Methods: A modified model of Data Envelopment Analysis (DEA) has been used in order to combine several financial indicators simultaneously in a unique efficiency measure. The model provides a rounded judgement on a bank's relative efficiency. Results: Efficiency of individual banks varied throughout the observed period and not all of the banks were a part of the negative banking sector trend induced by the crisis. There is no significant difference between performance of banks in different entities of Bosnia and Herzegovina, and between smaller and larger banks. Conclusions: The results of the study can be used by bank managers to assess the performance of their banks, as observing financial ratios separately can result in a misleading conclusion. The most valuable practical implications of the findings are the provided feasible targets for the three observed years.

Keywords: Banks, efficiency, Data Envelopment Analysis, financial ratios, Bosnia and Herzegovina

JEL main category: Macroeconomics and Monetary Economics

JEL classification: G21

Paper type: Research article

Received: 8, November, 2012

Revised: 4, March, 2013

Accepted: 6, April, 2013

Citation: Memić, D., Škaljić-Memić, S. (2013), "Performance Analysis and Benchmarking of Commercial Banks Operating in Bosnia and Herzegovina: a DEA Approach", Business Systems Research, Vol. 4, No. 2, pp. 17-37.

DOI: 10.2478/bsri-2013-0010

\section{Introduction}

Despite the fact that most of the banks respectively do follow the trends of the banking sector and record a negative orientation of basic business performance indicators, there is still a number of banks with better business results when compared to the previous years (CBBH Annual Report, 2010). Therefore, the study focuses on analysing individual business effectiveness of banks in Bosnia and Herzegovina, using financial ratio measures combined 
with the Data Envelopment Analysis (DEA) method in order to get a better understanding of the banking sector in the country. DEA is used in the research as a method which is considered as an alternative to the traditional ratio analysis (Feroz et al. 2003), when assessing the performance of analysed entities.

The main purpose of this study is the analysis and comparison of the efficiency of respective banks in the territory of Bosnia and Herzegovina (BH) by using financial ratio measures combined with the Data Envelopment Analysis (DEA) method. As part of the BH bank efficiency analysis and comparison, we compare the efficiency of banks in both Bosnia and Herzegovina entities, Federation of Bosnia and Herzegovina (FBH) and Republika Srpska (RS) Two entities are observed separately because of the peculiarity of the institutional and legal regulations of the banking sector in Bosnia and Herzegovina. The previous research shows that bank efficiency has often been linked to bank size and the amount of total assets (Chatzoglou et al. 2010; Derbali 2011; Fakhri et al. 2010; Kosmidou et al. 2006; Ramadan et al. 2011; Spathis et al. 2002), and thus the research focuses on exploring this link to the example of $\mathrm{BH}$ banks.

This research has threefold objective. The first objective is to determine individual efficiency of banks based on the overall efficiency score using the DEA method. This further enables comparisons between banks and gives insight on the trends of the banking sector in the period between 2008 and 2010. The second objective relates to comparing performances of banks in FBH and RS, taken the particular legal framework under which the banks operate. The last objective is to attempt to give an answer to whether smaller or bigger banks are more successful. Since the researchers conducted so far failed to give a harmonized answer to this question (Chatzoglou et al. 2010; Derbali 2011; Fakhri et al. 2010; Kosmidou et al. 2006; Ramadan et al. 201 1; Spathis et al. 2002), the author aims at offering a concrete answer using the example of banks in FBH. Finally, we summarize the research questions in the following manner:

\section{RQ1. What is the score of individual efficiency of BH banks? \\ $R Q 2$. Are banks in FBH more efficient than banks in RS? $R Q 3$. Are smaller banks in BH more efficient than large ones?}

To our knowledge, this is the first research conducted so far with the aim of benchmarking the efficiency of banks in BH, applying the DEA. The significance of the research is that it offers an insight into the individual bank efficiencies calculated through a combination of multiple financial indicators, which enables a better overview of the banking sector in $\mathrm{BH}$. It is also useful for the bank management as it enables managers to get a real sense of the bank's position when compared to the competition and enhance their efficiency by adopting certain business practices of top ranking banks. Finally, the DEA helped identify feasible improvement targets for inefficient banks.

\section{Literature review}

\section{Measuring Banks' Performance}

The role of banks in any economy can be qualified as crucial since they serve as financial mediators on financial markets. Their successful dealings positively affect the stability of the financial sector and certainly contribute to economic growth. Therefore it doesn't come as a surprise that a huge number of researches in the field of banking focus precisely on measuring and comparing bank performances and identifying main factors that affect their success (Chen \& Yeh 2000; Kosmidou et al. 2006; Spathis et al. 2002; Alper \& Anbar 2011; Chatzoglou et al. 2010; Chien-Ta Ho \& Wu 2006; Mostafa 2007; Shanling Li et al. 2001; Ramadan et al. 2011; G. Halkos 2004; Jemric \& Vujcic 2002; G. E. Halkos \& Salamouris 2004; Gaganis et al. 2009; Kumar \& Gulati 2010; Berg et al. 1991; Goddard et al. 2004; Ozkan-Gunay \& Tektas 2006; Ramanathan 2007).

Several financial performance measures such as profitability or liquidity are used in the reviewed research, whereas financial ratio measures are most commonly used. The advantage of these measures is that they are not expressed in absolute, but in relative terms, thus eliminating the influence of inflation, currency differences and size issues, when comparing different entities. Due to the above-mentioned characteristics, they are suitable for bank performance comparisons among several countries and through a longer period of 
time. For example, Alam et al. (2011) offer a financial performance comparison of public vs. private banks in Pakistan from 2006-2009, taking in consideration the average values of four financial ratios measures: efficiency ratios, liquidity ratios, asset quality ratios and capital ratios. The same method was used by Shanling Li et al. (2001) for comparing performances of Chinese banks. They worked with a sample of 15 banks in total, dividing them in three groups, depending on their ownership structure and calculated the average values of 9 ratio indicators, including net interest margin, asset utilization, etc. Šarlija \& Harc (2012) investigated the impact of liquidity on the capital structure of Croatian firms using several liquidity ratios.

The increased use of financial versus non-financial measures is also evident in the results of the study by Fakhri et al.(2010) conducted on a sample of 95 medium and high-level bank managers. The study was implemented with the purpose of researching the usage of financial and non-financial performance measures in the banking sector. However, the financial ratio analysis used in the above-mentioned studies has certain shortcomings, since the results of both studies show that according to certain indicators, one group of banks is more successful, while according to other indicators another group of banks is characterized by more success. Since there are no standard criteria to determine which indicators bear more significance, it was not possible to determine which group of banks has better overall performances. Because of these and similar reasons, most authors use ratio measures only as a starting point for the further application of statistical and mathematical models.

Ho (2006) measured performance and ranked 3 Taiwanese commercial banks, applying the Gray Relation Analysis (GRA) to 38 financial ratio indicators listed in five categories: profitability, liquidity, efficiency, security and growth. The goal of GRA application is to reduce the number of ratio indicators and to single out representative indicators. Calculating the grey relation coefficient, 17 most significant and most representative indicators were singled out. In order to get an overall performance result for every single bank as to eventually rank them according to their performance, TOPSIS method was applied. The authors compared the obtained results with the results of the Financial Statement Analysis and proved the superiority of the GRA method. The same method was applied by Ho and WU (2006) for ranking the 3 largest Australian banks, as they chose 59 financial indicators, which were narrowed down to 23 using GRA method. Vojvodic Rosenzweig, Volarevic, Varovic, M. (2012) proposed ranking of banks based on six financial criteria using a multi-criteria approach using a goal programming model. The results showed that in ranking of banks the highest priority is given to profitability and credit risk.

Kosmidou and Zopounidis (2008) ranked 30 Greek banks according to their performances as they utilized multi-criteria PROMETHEE method using 11 financial ratio indicators, including: net income before taxes/ equity (ROE) and net income before taxes/total assets (ROA) as variables. The performance of Greek banks was also evaluated by Spathis et al.(2002) using two multi-criteria methodologies: UTADIS and MHDIS by applying the 10-fold-cross-validation approach. Seven financial indicators were selected as evaluation criteria including: return on assets, return on equity and net interest margin. The research encompasses a sample of 23 banks on the territory of Greece, excluding foreign banks. Panel data was used and banks were divided into two groups: small and large banks. The results showed greater performance of larger banks in relation to small ones. Positive relation between the size of banks and their profitability was also proved in the results of a study conducted by Derbali (2011) applying the correlation and regression analysis and using net interest margin as a profitability ratio on 11 Tunisian commercial banks.

On the other side, research conducted by Kosmidou et al. (2006) showed better business performance of smaller banks using UK dataset. Criteria used to categorize banks according to their size were their overall assets (banks with assets up to $£ 100,000$ million were listed in the category of small banks). The authors used panel data of 40 banks in the period between 1998 and 2002 and applied PAIRCLASS multi-criteria method with 10-fold cross validation approach. Similar results were reported in the research conducted by Ramadan et al. (2011). The aim of the study was to identify profitability determinants of banks in Jordan. ROA and ROE were used as profitability measures along with the data for 10 banks in the period between 2001 and 2010. Linear regression model was applied in the research and the results showed that the profitability of Jordanian banks stands in negative relation to size and in 
positive relation to good capitalization, high lending activities, low credit risk, and the efficiency of cost management.

Another research conducted by Alper and Anbar (2011) analyses the influence of external and internal factors on bank profitability in Turkey. ROA and ROE as two measures of profitability were used as dependent variables, while the total assets, capital adequacy, liquidity, deposits and asset quality (internal determinants), as well as the annual inflation rate, real interest rate and annual GDP growth rate (external determinants) were used as independent variables. The research was conducted on 10 commercial banks from 2002 to 2010. The authors found that asset size has a significant effect on bank's profitability, while low asset quality reduces profitability. The only external variable, among all chosen, that had a significant effect on profitability is real interest rate.

A similar research conducted by Bach et al (2006) on the example of Croatian banks examined the profitability determinants of Croatian banks using macroeconomic factors (GDP, inflation), as well as bank specific factors (market participation, the ratio of stock capital to the overall property, NIM, the relation of operational costs to the overall property, etc.). The authors used multiple linear regression with the dependent variables ROA and ROE. The research encompasses the period between 1999 and 2005. The results revealed that, in stabile macroeconomic conditions, efficient cost management and capitalization of banks are in positive relation to profitability as well as market participation of banks.

\section{Data Envelopment Analysis for Measuring Banks' Performance}

DEA is a non-parametric method based on the linear programming model, which is being used for performance measurement of Decision Making Units (DMUs). By DMUs we considered all subjects which are able to convert inputs into outputs. The DEA method was first presented by Charnes et al. (1978). As time passed, variations of their initial model evolved, increasing thus the popularity of the DEA method (Banker et al. 1984; Zhu 2003).

The main goal of DEA is to use a set of similar DMUs as to determine which one of them has the best performances in relation to the others. Such a unit is considered to be standard and other observed DMUs are compared to it. Given that the DAE evaluates performance of DMUs as a weighted sum of outputs to the weighted sum of inputs, its most common use is for measuring the efficiency of DMUs. It is important to note that this efficiency is not absolute, but rather relative, since it is assessed through the relations to other DMUs. A definition of relative DMUs efficiency was provided by Cooper (2010): „A DMU is to be rated as fully (100 percent) efficiencies on the basis of available evidence if and only if the performance of other DMUs does not show that some of its inputs or outputs can be improved without worsening some of its other inputs or outputs". Using DEA enables DMUs ranking according to their efficiency scores. It also identifies how much input must be reduced or outputs increased in order for DMUs to become efficient.

DEA has its advantages as well as disadvantages. The main advantages of DEA method are that it can be easily applied to small samples, no assumption has to be fulfilled about functional or statistic distribution and it gives an overall efficiency score for each DMU. The main disadvantages of DEA method are that it assumes data to be free of measurement error and it is sensitive to outliers. The occurrence of outliers shows results were "it is possible that some of the inefficient DMUs are in fact better performers than certain efficient ones" (Talluri, 2000). However, DEA model is better than the financial ratio analysis in the sense that it "forms a rounded judgment on DMUs efficiency, taking into consideration a variety of ratios simultaneously and combining them into a single measure of efficiency" (G. E. Halkos \& Salamouris 2004).

Data Envelopment Analysis is widely used not only for the assessment of bank performance, but also for measuring the performances of other subjects, such as, for example, universities. (Ulucan 2011), hospitals (Ozcan \& McCue 1996), hotels (Keh et al. 2006), airports (Koçak 2011) and even football teams (Garcia-Sánchez 2007).

Ramanathan (2007) applied DEA in order to assess the performance of 55 commercial banks from 6 countries: Kuwait, Qatar, Bahrain, Oman, Saudi Arabia and the United Arabic Emirates. Data for the year 2004 were analysed in the study. The inputs used for the DEA were: fixed assets, deposits, equity and personnel expenses, while loans and other earning assets were 
used as outputs. According to the results of the research, only 15 out of 55 banks had efficient business dealings in 2004, meaning that they have achieved maximum outputs for the given inputs.

Mostafa (2007) conducted a benchmarking of 85 Arabic banks in 2005, using DEA. Equity and total assets were used an inputs, while net profit, return on equity and return on assets were used as outputs. The research resulted in the creation of a ranking list in which only 8 banks proved to have a maximum efficiency score, while other banks were insufficiently efficient or even inefficient. This and similar research enables managers to get a real sense of the bank's position when compared to the competition and enhance their efficiency by adopting certain business practices of top ranking banks.

Ozkan-Gunay and Tektas (2006) used the DEA model in order to analyse the efficiency of banks in Turkey in the period between 1990 and 2001. In that period of time, two financial crises hit Turkey, the first being in 1994, and the second in 2001. The main objective of the study was to estimate the influence of the crises on commercial banks in Turkey. The results show an evident decrease trend when it comes to the number of efficient banks in the period of research. In addition, $25 \%$ of local commercial banks were taken over by the foreign Saving Deposits Insurance Fund. The banks that were taken over were significantly more inefficient than the remaining banks on the market.

Applying the DEA, Chen and Yeh (2000) measured relative efficiency of 34 commercial banks in Taiwan since 1996. In addition to individual efficiency evaluation of banks and their ranking, they also compared the efficiency of banks depending on their ownership structure. Out of 34 banks, 11 proved to be efficient. Furthermore, 10 of them were private and one was state-owned. Average technical efficiency scores of state-owned banks was significantly lower than that of private banks.

The Data Envelopment Analysis was also used to assess efficiency of banks in Croatia. In their study, Jemric and Vujcic (2002) used data for the period between 1995 and 2000, taking interest and related costs, commissions for services and related costs and administrative costs as their inputs and interest and related revenues as their outputs. For analytical purposes, banks are grouped according to ownership structure: state owned, private domestic and foreign, and according to age: old (founded before 1990) and new (founded in 1990 or later). The DEA shows that foreign owned banks in Croatia attained better business results than banks owned by local entities and that new banks were more efficient than old ones.

The research done by Kumar and Gulati (2010) applied a two-stage DEA model for evaluating bank performances. In stage one was measured bank efficiency tracking fixed assets labour (number of employees) and loanable funds (sum of deposits and borrowings) as inputs, and investments and "advances" as outputs. In second stage bank's effectiveness was measured by taking outputs of the first stage (Investments and advances) as inputs, while „net-interest income and non-interest income was used as outputs. The model described calculates overall bank performances as a product of their effectiveness and efficiency measures. The model has been applied to a sample of 27 banks in the time between 2006 and 2007. The conclusion of the research was that bank efficiency does not imply their effectiveness. The same methodology was applied by Sultan et al. (2011) for measurement of bank performances in Pakistan. The study encompassed 10 banks in the period between 2005 and 2009. The results confirm that there is no necessary correlation between efficiency and effectiveness of banks.

A two-stage DEA was also used by Tsolas (2010) in order to assess performances within the branches of a large Greek bank. Halkos and Salamouris (2004) presented a modified DEA model for assessing bank efficiency. The main assumption of the model is that the inputs are similar or even same for all banks since they operate on the same market and offer the same services. That is why this model does not directly take inputs into consideration, only outputs in the form of financial ratio indicators. Respecting the main assumption of the model itself, the research was conducted on commercial banks in Greece, using data for the period between 1997 and 1999. The outputs used included the following financial ratios: return on equity, return on assets, net interest margin, profit/loss per employee, efficiency ratio and return difference of interest bearing assets. The results indicated which banks were efficient and determined feasible targets for the enhancement of other banks' efficiency. 
The same model was applied by Chatzoglou et al. (2010) using: ROA, ROE, efficiency ratio, net interest margin and profit/loss per employee as outputs. The analysis included data of 10 Greek commercial banks in the period from 2003-2006. The results were compared to the standard DEA model in which the following input was used: total assets, labour and operational expenses, while net profit was used as the output. Research has shown the similarity of the results obtained in both models. Also a positive correlation between the size of banks (as measured by total assets) and its performance was determined.

This overview of literature shows that, even though a great number of studies on bank performance assessment were conducted using the DEA method, none of those studies known to the author ever included banks in Bosnia and Herzegovina. This work shall attempt to fill in this research gap. Bosnia and Herzegovina's banking market will face the increasing needs of efficiency improvements as joining the European Union becomes a more actual topic. The war aftermath, constitutional constraints and complex political setup, had a negative influence on the Bosnian economy, transition process, its financial markets and the overall efficiency. This research has an aim of giving an additional insight into the current efficiency of the banking sector as well as to detect banking leaders and under-performers. The author shall apply the modified DEA model referring to the studies of Halkos and Salamouris (2004) and Chatzoglou et al.(2010).

\section{Methodology}

In this research modified DEA model was applied which, unlike the conventional models, uses financial ratios as outputs while inputs are not taken directly into consideration. There are two reasons justifying the absence of inputs: the fact that inputs are already included indirectly in the model through ratios, for example ROA as output variable is actually the ratio of profit and total assets where assets could be considered as input; and the basic assumption of this model that all banks from the sample operate in the same market and offer the same types of services so they use similar or equal inputs. Because of its features, this model "constitutes an interesting alternative for efficient evaluation and a complement to the simple ratio analysis" (G. E. Halkos \& Salamouris 2004).

As it is suggested by Halkos and Salamouris (2004) the modified DEA model can be written as a linear programming problem in the following form:

$$
\begin{aligned}
& \operatorname{Max} \vartheta_{l} \\
& \text { subject to } \sum_{n=1}^{N} \lambda_{n} R_{i n} \geq \vartheta_{l} R_{i l} \quad(\mathrm{i}=1,2, \ldots \ldots, \mathrm{m}) \\
& \\
& \sum_{\mathrm{n}=1}^{N} \lambda_{n}=1 \\
& \vartheta_{l} \geq 0 \\
& \lambda_{\mathrm{n}} \geq 0 \quad(\mathrm{n}=1,2, \ldots \ldots ., \mathrm{N})
\end{aligned}
$$

where $\mathrm{N}$ represents the number of banks under the consideration; $\mathrm{R}_{\mathrm{i}}$ represents a vector of outputs $(i=1,2, \ldots, \mathrm{m})$ for each bank $n(n=1,2 \ldots, N)$; and $\lambda_{n}$ represents weight placed on each of the banks in forming the efficient frontier for bank (I). The efficiency score for each bank is given by $\vartheta_{1}=1 / \vartheta_{1}$ and it can take values between 0 and $1(0 \leq \theta \leq 1)$. Banks with the efficiency score equal to one are considered efficient, while those with efficiency score less than one are less efficient or inefficient.

If bank I is considered inefficient then a feasible target for improvement in each ratio $R_{i}$ for bank $I$ is defined by:

$$
\hat{\mathrm{Y}}_{i l}=\sum_{n=1}^{N} \lambda_{n}^{*} R_{i n}
$$


where $\lambda_{n}^{*}(n=1,2, \ldots . N)$ represent optimal weights of the reference group for bank I. Further, it is possible that some banks exhibit negative outputs. Because it would compromise the inequality in Eq (1), Halkos and Salamouris (2004) suggested that in such cases, the constraint associated with the negative ratio should be modified to the following:

$$
\sum_{n=1}^{N} \lambda_{n} R_{i n} \geq R_{i l}
$$

This modification would ensure that the reference group not exhibit worse performance than a reference bank on the output where that bank has negative performance. Following is the description of the research sample and data sources.

\section{Research Sample and Data Sources}

The research is conducted in 26 out of 29 commercial banks operating on BH market. Three banks that were excluded from the research are: Bosnia Bank International which conducts its business activities according to the principles of Islamic banking; Postbank and Hercegovacka Banka which are both under the interim administration. In order to evaluate the efficiency of banks, secondary sources of data were used, including a financial report of banks operating in Bosnia and Herzegovina from banking regulatory authorities in both Bosnian entities. The research covered the period of three years, including 2008, 2009 and 2010.

Five financial ratios were chosen to reflect efficiency as well as profitability dimensions of banks' performance. Five chosen ratios are presented in Table 1. Return on Equity (ROE) is one of the main profitability measures used in the banking sector (Rose 2001, p. 158). It shows the rate of return on each EUR of equity invested in the bank. Return on Assets (ROA) shows to which extent is managers efficient in converting bank's assets into profit (Kapor 2005, p.285). Net Interest Margin (NIM) measures the difference between interest income and interest expenses relative to total assets of a bank. It shows the bank's spread per EUR of assets (CasU et al. 2006, p.217). Profit/Loss per employee (P/L) measures the management ability to use labour resources effectively to generate profit for the bank. Efficiency Ratio (EFF) is a "measure of how effective a bank is in using overhead expenses including salaries and benefit costs and occupancy expenses as well as other operating expenses in generating revenues"(Hays et al. 2009). Lower EFF ratio indicates greater efficiency of a bank and vice versa. Therefore, for the convenience with the other ratios in this research, inversed form of EFF (1/EFF) will be used, as suggested by Chatzoglou et al. (2010).

Table 1

Financial ratios used as a measures of banks' profitability

\begin{tabular}{ccc}
\hline Abriviation & Financial ratio name & Financial ratio \\
\hline ROE & Return on Assets & Profit before taxes/Assets \\
ROA & Return on Equity & Profit before taxes/Equity \\
NIM & Net Interest Margin & (Interest income-Interest expenses) /Total assets \\
$P / L$ & Profit/Loss per employee & Result before Taxes/Number of employees \\
EFF & Efficiency Ratio & Non Interest Expences/(Net Interest income+ Non \\
& & Interest Expences) \\
\hline
\end{tabular}

Source: Van Horne, J.C., Wachowicz J.M. (2001)

Five chosen financial ratios were calculated for all analysed banks operating in two Bosnia and Herzegovina entities, for each of the three analysed periods (banks are listed in Appendices 1-3).

The next table represents a DEA model for 26 banks operating in Bosnia and Herzegovina. This overview consists of efficiency ratios calculated for all of the banks based on the methodology suggested by Halkos and Salamouris (2004) for the observed period between 
2008 and 2010. Each bank received a corresponding efficiency ratio $(\theta)$ for each year. The efficiency ratios have been assessed using five financial ratios: ROA, ROE, NIM, 1/EFF and P/L.

Table 2

Efficiency ratios for period 2008-2010

\begin{tabular}{|c|c|c|c|c|c|c|c|c|}
\hline 2008 & $\theta$ & Rank & 2009 & $\theta$ & Rank & 2010 & $\theta$ & Rank \\
\hline $\begin{array}{l}\text { ProCredit } \\
\text { Bank }\end{array}$ & 1.00 & 1 & $\begin{array}{l}\text { ProCredit } \\
\text { Bank }\end{array}$ & 1.00 & 1 & $\begin{array}{l}\text { ProCredit } \\
\text { Bank }\end{array}$ & 1.00 & 1 \\
\hline $\begin{array}{l}\text { UniCredit } \\
\text { Bank }\end{array}$ & 1.00 & 1 & $\begin{array}{l}\text { UniCredit } \\
\text { Bank }\end{array}$ & 1.00 & 1 & $\begin{array}{l}\text { UniCredit } \\
\text { Bank }\end{array}$ & 1.00 & 1 \\
\hline $\begin{array}{l}\text { I.K banka } \\
\text { Zenica }\end{array}$ & 1.00 & 1 & Turkish Ziraat & 1.00 & 1 & $\begin{array}{l}\text { I.K banka } \\
\text { Zenica }\end{array}$ & 1.00 & 1 \\
\hline $\begin{array}{l}\text { Privredna } \\
\text { banka }\end{array}$ & 1.00 & 1 & $\begin{array}{l}\text { KIB Velika } \\
\text { Kladusa }\end{array}$ & 1.00 & 1 & $\begin{array}{l}\text { KIB Velika } \\
\text { Kladusa }\end{array}$ & 1.00 & 1 \\
\hline NLB Razvojna & 1.00 & 1 & Nova Banka & 1.00 & 1 & Bor Banka & 1.00 & 1 \\
\hline Turkish Ziraat & 0.97 & 6 & $\mathrm{BIB}$ & 0.95 & 6 & $\begin{array}{l}\text { NLB } \\
\text { Razvojna }\end{array}$ & 1.00 & 1 \\
\hline NLB & 0.96 & 7 & $\begin{array}{l}\text { Privredna } \\
\text { banka }\end{array}$ & 0.95 & 7 & $\begin{array}{l}\text { Pavlović } \\
\text { International }\end{array}$ & 1.00 & 1 \\
\hline Bor Banka & 0.93 & 8 & Bor Banka & 0.93 & 8 & $\begin{array}{l}\text { Volksbank } \\
\text { B.L }\end{array}$ & 1.00 & 1 \\
\hline $\begin{array}{l}\text { KIB Velika } \\
\text { Kladusa }\end{array}$ & 0.91 & 9 & $\begin{array}{l}\text { I.K banka } \\
\text { Zenica }\end{array}$ & 0.92 & 9 & Nova Banka & 1.00 & 1 \\
\hline $\begin{array}{l}\text { Pavlović } \\
\text { International }\end{array}$ & 0.90 & 10 & $\begin{array}{l}\text { Volksbank } \\
\mathrm{BH}\end{array}$ & 0.85 & 10 & $\begin{array}{l}\text { Unicredit } \\
\text { Bank B.L }\end{array}$ & 1.00 & 1 \\
\hline BIB & 0.85 & 11 & $\begin{array}{l}\text { Intesa San } \\
\text { Paolo }\end{array}$ & 0.85 & 10 & MF Banka & 1.00 & 1 \\
\hline $\begin{array}{l}\text { Raiffeisen } \\
\text { Bank }\end{array}$ & 0.80 & 12 & $\begin{array}{l}\text { Raiffeisen } \\
\text { Bank }\end{array}$ & 0.84 & 12 & Bobar Banka & 0.99 & 12 \\
\hline $\begin{array}{l}\text { Volksbank } \\
\text { B.L }\end{array}$ & 0.79 & 13 & $\begin{array}{l}\text { Komercijalna } \\
\text { Banka }\end{array}$ & 0.83 & 13 & Turkish Ziraat & 0.96 & 13 \\
\hline $\begin{array}{l}\text { Volksbank } \\
\text { BH }\end{array}$ & 0.75 & 14 & $\begin{array}{l}\text { Unicredit } \\
\text { Bank B.L }\end{array}$ & 0.83 & 13 & $\begin{array}{l}\text { Intesa San } \\
\text { Paolo }\end{array}$ & 0.93 & 14 \\
\hline Hypo B.L & 0.71 & 15 & Bobar Banka & 0.82 & 15 & Sparkasse & 0.93 & 14 \\
\hline $\begin{array}{l}\text { Unicredit } \\
\text { Bank B.L }\end{array}$ & 0.70 & 16 & $\begin{array}{l}\text { Volksbank } \\
\text { B.L }\end{array}$ & 0.82 & 15 & $\begin{array}{l}\text { Vakufska } \\
\text { Banka }\end{array}$ & 0.91 & 16 \\
\hline $\begin{array}{l}\text { Vakufska } \\
\text { Banka }\end{array}$ & 0.67 & 17 & Hypo B.L & 0.81 & 17 & $\begin{array}{l}\text { Komercijalna } \\
\text { Banka }\end{array}$ & 0.90 & 17 \\
\hline Nova Banka & 0.60 & 18 & NLB & 0.80 & 18 & $\begin{array}{l}\text { Raiffeisen } \\
\text { Bank }\end{array}$ & 0.86 & 18 \\
\hline Intesa San & 0.55 & 19 & Union Banka & 0.80 & 18 & Volksbank & 0.83 & 19 \\
\hline Paolo & & & & & & $\mathrm{BH}$ & & \\
\hline Union Banka & 0.54 & 20 & $\begin{array}{l}\text { Pavlović } \\
\text { International }\end{array}$ & 0.77 & 20 & $\begin{array}{l}\text { Privredna } \\
\text { banka }\end{array}$ & 0.82 & 20 \\
\hline $\begin{array}{l}\text { Komercijalna } \\
\text { Banka }\end{array}$ & 0.51 & 21 & $\begin{array}{l}\text { Vakufska } \\
\text { Banka }\end{array}$ & 0.75 & 21 & NLB & 0.80 & 21 \\
\hline MF Banka & 0.38 & 22 & Нуро & 0.71 & 22 & $\mathrm{BIB}$ & 0.76 & 22 \\
\hline Bobar Banka & 0.38 & 23 & $\begin{array}{l}\text { NLB } \\
\text { Razvojna }\end{array}$ & 0.71 & 22 & Union Banka & 0.72 & 23 \\
\hline Sparkasse & 0.37 & 24 & Sparkasse & 0.66 & 24 & Hypo B.L & 0.67 & 24 \\
\hline Нуро & 0.35 & 25 & Moja Banka & 0.52 & 25 & Moja Banka & 0.63 & 25 \\
\hline Moja Banka & 0.33 & 26 & MF Banka & 0.30 & 26 & Нуро & 0.59 & 26 \\
\hline Average $\theta$ & 0.73 & & & 0.82 & & & 0.90 & \\
\hline Maximum $\theta$ & 1.00 & & & 1.00 & & & 1.00 & \\
\hline Minimum $\theta$ & 0.33 & & & 0.30 & & & 0.59 & \\
\hline
\end{tabular}

Source: Author's calculations

Since the efficiency ratio $(\theta)$ takes values from 0 to 1 , the bank with an efficiency ratio equal to 1 is considered as the most efficient one. Banks were ranked according to the calculated efficiency ratio in all of the three years. Five banks received the highest efficiency ratio (equal to 1) in 2008 (ProCredit Bank, UniCredit Bank, I.K. banka, Provredna banka and 
NLB razvojna banka). The least efficient banks in 2008 were MF banka, Bobar banka, Sparkasse Hypo Mostar and Moja banka. An average $\theta$ for 2008 is 0.73.

The DEA efficiency ratios are calculated for 2009. The number of highly efficient banks was the same as it was in 2008. However, the structure of the most efficient banks changed. ProCredit bank and UniCredit bank retained among the highly efficient banks, while Turkish Ziraat, KIB and Nova banka replaced IK, Privredna and NLB Razvojna banka. The least efficient banks according to the DEA results in 2009 were once again MF banka, Sparkasse, Hypo Mostar and Moja banka, with an addition of NLB Razvojna banka. An average $\theta$ for 2009 is 0.82 and it improved when compared to the previous year, showing better overall banking sector efficiency.

The DEA analysis for 2010 showed that the overall efficiency in the banking sector $\mathrm{BH}$ improved when compared to the previous two years, as the average $\theta$ increased to 0.90 . Eleven banks received the highest value of efficiency factor. ProCredit Bank, UniCredit Bank, KIB and Nova banka retained among the highly efficient banks, joined by IK, Bor banka and NLB razvojna banka, Pavlovic International, Volskbank B.L., UniCredit Bank B.L. and MF banka. The latest bank was among the least efficient banks in 2008 and 2009 and showed a significant improvement during 2010. The least efficient banks according to the DEA results in 2010 were once again Hypo Mostar and Moja banka, and were joined by BIB (Balkan Investment bank), Union Banka and Hypo B.L.

Table 3

Ranking of banks based on the average efficiency ratio

\begin{tabular}{|c|c|c|c|c|c|c|}
\hline Bank & $\theta 2008$ & $\theta 2009$ & $\theta 2010$ & $\theta$ Average & Rank & Interpretation \\
\hline ProCredit Bank & 1.00 & 1.00 & 1.00 & 1.00 & 1 & Highly efficient \\
\hline UniCredit Bank & 1.00 & 1.00 & 1.00 & 1.00 & 1 & \\
\hline Turkish Ziraat & 0.97 & 1.00 & 0.96 & 0.98 & 3 & \\
\hline I.K banka Zenica & 1.00 & 0.92 & 1.00 & 0.97 & 4 & \\
\hline KIB Velika Kladusa & 0.91 & 1.00 & 1.00 & 0.97 & 5 & \\
\hline Bor Banka & 0.93 & 0.93 & 1.00 & 0.95 & 6 & \\
\hline Privredna banka & 1.00 & 0.95 & 0.82 & 0.92 & 7 & \\
\hline NLB Razvojna & 1.00 & 0.71 & 1.00 & 0.90 & 8 & \\
\hline $\begin{array}{l}\text { Pavlović } \\
\text { International }\end{array}$ & 0.90 & 0.77 & 1.00 & 0.89 & 9 & $\begin{array}{l}\text { Relatively } \\
\text { efficient }\end{array}$ \\
\hline Volksbank B.L & 0.79 & 0.82 & 1.00 & 0.87 & 10 & \\
\hline Nova Banka & 0.60 & 1.00 & 1.00 & 0.87 & 11 & \\
\hline $\begin{array}{l}\text { Balkan Investment } \\
\text { Bank }\end{array}$ & 0.85 & 0.95 & 0.76 & 0.86 & 12 & \\
\hline NLB & 0.96 & 0.80 & 0.80 & 0.85 & 13 & \\
\hline Unicredit Bank B.L & 0.70 & 0.83 & 1.00 & 0.84 & 14 & \\
\hline Raiffeisen Bank & 0.80 & 0.84 & 0.86 & 0.84 & 15 & \\
\hline Volksbank BH & 0.75 & 0.85 & 0.83 & 0.81 & 16 & \\
\hline Intesa San Paolo & 0.55 & 0.85 & 0.93 & 0.78 & 17 & $\begin{array}{l}\text { Average } \\
\text { efficient }\end{array}$ \\
\hline Vakufska Banka & 0.67 & 0.75 & 0.91 & 0.78 & 18 & \\
\hline Komercijalna Banka & 0.51 & 0.83 & 0.90 & 0.75 & 19 & \\
\hline Hypo B.L & 0.71 & 0.81 & 0.67 & 0.73 & 20 & \\
\hline Bobar Banka & 0.38 & 0.82 & 0.99 & 0.73 & 21 & \\
\hline Union Banka & 0.54 & 0.80 & 0.72 & 0.69 & 22 & Inefficient \\
\hline Sparkasse & 0.37 & 0.66 & 0.93 & 0.65 & 23 & \\
\hline MF Banka & 0.38 & 0.30 & 1.00 & 0.56 & 24 & \\
\hline Нуро & 0.35 & 0.71 & 0.59 & 0.55 & 25 & \\
\hline Moja Banka & 0.33 & 0.52 & 0.63 & 0.49 & 26 & \\
\hline Average efficiency & 0.73 & 0.82 & 0.90 & 0.82 & & \\
\hline Maximum efficiency & 1.00 & 1.00 & 1.00 & & & \\
\hline Minimum efficiency & 0.33 & 0.30 & 0.59 & & & \\
\hline
\end{tabular}

Source: Author's calculations

It can be concluded that the overall efficiency of the banking sector has improved over the observed period between 2008 and 2010, even though the profitability has declined 
significantly and it can be seen in the next graph. The sensibility of DEA to outliers, while assessing the desired efficiency factor, has already been mentioned as a disadvantage of this technique.

The banks have been assigned a final ranking, based on average efficiency ratios for the three observed years, which are given in the next table. The efficiency ratios are calculated based on linear programming model suggested by Halkos and Salamouris (2004). ProCredit and UniCredit are the only two banks which had the highest possible efficiency in all three years and have received rank 1 for that reason. Moja banka. Hypo Mostar and MF banka are the least efficient banks in the period between 2008 and 2010. All of the analysed banks have been selected one of the four predefined efficiency groups, based on the value of the average $\theta$ : highly efficient, relatively efficient, average efficient and inefficient.

Table 4

DEA comparison between larger and smaller banks

\begin{tabular}{|c|c|c|c|c|c|c|c|}
\hline Bank & Size & Assets & $\theta 2008$ & Assets & $\theta 2009$ & Assets & $\theta 2010$ \\
\hline Hyро & $\mathrm{L}$ & 951 & 0.35 & 1,147 & 0.71 & 1,243 & 0.59 \\
\hline Hуро B.L & L & 775 & 0.71 & 852 & 0.81 & 979 & 0.67 \\
\hline $\begin{array}{l}\text { Intesa San } \\
\text { Paolo }\end{array}$ & $\mathrm{L}$ & 658 & 0.55 & 596 & 0.85 & 520 & 0.93 \\
\hline NLB Razvojna & L & 538 & 1.00 & 594 & 0.71 & 636 & 1.00 \\
\hline Raiffeisen Bank & L & 1,913 & 0.80 & 2,154 & 0.84 & 2,197 & 0.86 \\
\hline UniCredit Bank & L & 1,844 & 1.00 & 1,768 & 1.00 & 1,692 & 1.00 \\
\hline $\begin{array}{l}\text { Balkan } \\
\text { Investment } \\
\text { Bank }\end{array}$ & $S$ & 138 & 0.85 & 130 & 0.95 & 116 & 0.76 \\
\hline Bobar Banka & S & 113 & 0.38 & 100 & 0.82 & 96 & 0.99 \\
\hline Bor Banka & S & 78 & 0.93 & 59 & 0.93 & 53 & 1.00 \\
\hline $\begin{array}{l}\text { I.K banka } \\
\text { Zenica }\end{array}$ & S & 91 & 1.00 & 86 & 0.92 & 78 & 1.00 \\
\hline $\begin{array}{l}\text { KIB Velika } \\
\text { Kladusa }\end{array}$ & S & 31 & 0.91 & 28 & 1.00 & 28 & 1.00 \\
\hline $\begin{array}{l}\text { Komercijalna } \\
\text { Banka }\end{array}$ & S & 121 & 0.51 & 110 & 0.83 & 112 & 0.90 \\
\hline MF Banka & S & 16 & 0.38 & 13 & 0.30 & 16 & 1.00 \\
\hline Moja Banka & S & 74 & 0.33 & 64 & 0.52 & 57 & 0.63 \\
\hline NLB & S & 478 & 0.96 & 429 & 0.80 & 405 & 0.80 \\
\hline Nova Banka & S & 429 & 0.60 & 418 & 1.00 & 388 & 1.00 \\
\hline $\begin{array}{l}\text { Pavlović } \\
\text { International }\end{array}$ & $S$ & 86 & 0.90 & 77 & 0.77 & 70 & 1.00 \\
\hline $\begin{array}{l}\text { Privredna } \\
\text { banka }\end{array}$ & S & 109 & 1.00 & 81 & 0.95 & 52 & 0.82 \\
\hline ProCredit Bank & S & 156 & 1.00 & 173 & 1.00 & 240 & 1.00 \\
\hline Sparkasse & $S$ & 399 & 0.37 & 336 & 0.66 & 270 & 0.93 \\
\hline Turkish Ziraat & S & 88 & 0.97 & 79 & 1.00 & 76 & 0.96 \\
\hline $\begin{array}{l}\text { Unicredit Bank } \\
\text { B.L }\end{array}$ & S & 296 & 0.70 & 317 & 0.83 & 325 & 1.00 \\
\hline Union Banka & S & 85 & 0.54 & 75 & 0.80 & 88 & 0.72 \\
\hline Vakufska Banka & S & 111 & 0.67 & 98 & 0.75 & 87 & 0.91 \\
\hline Volksbank B.L & $S$ & 216 & 0.79 & 196 & 0.82 & 237 & 1.00 \\
\hline Volksbank BH & S & 412 & 0.75 & 406 & 0.85 & 439 & 0.83 \\
\hline Total assets & & 10,209 & & 10,387 & & 10,498 & \\
\hline Median assets & & 147 & & 152 & & 176 & \\
\hline $\begin{array}{l}\text { Average } \\
\text { efficiency }\end{array}$ & & 0.73 & & 0.82 & & 0.90 & \\
\hline
\end{tabular}

Source: Author's calculations

Since the used sample includes nearly all of the banks operating in Bosnia and Herzegovina (with an exclusion of some banks that do not fulfil the needs of this research) the average efficiency of the banking sector of Bosnia and Herzegovina of 82 percent can be considered as satisfactory. If some of the inefficient banks managed to improve their main 
financial indicators, the overall sector efficiency could be improved significantly. That is one of the reasons why feasible targets for each bank and each period have been calculated. Feasible targets represent the desired values of analysed financial ratios that need to be achieved in a certain bank in order to be considered as highly efficient $(\theta=1)$. Three different tables are given in Appendices 4-6, each containing a reported value of a certain financial indicator, along with a feasible target (in parentheses).

An interesting question posed in the research is whether large banks are more efficient and productive than smaller banks operating in Bosnia and Herzegovina. For the purpose of this study all of the 26 banks in the sample are divided into two groups: (i) Large banks with assets value above 511.291 EUR (ii) Small banks with assets value bellow 511.291 EUR.

If this condition is applied to the analysed data, six banks are regarded as large banks (Hypo Mostar, Hypo B.L., Intesa San Paolo, NLB Razvojna, Raiffeisen bank and Unicredit bank), while the remaining 20 are classified as small banks (Balkan Investmen Bank, Bobar Banka, Bor Banka, I.K. Banka, KIB banka, Komercijalna banka, MF Banka, Moja Banka, NLB, Nova Banka, Pavlovic International, Privredna banka, ProCredit Bank, Sparkasse, Turkish Ziraat, UniCredit Bank B.L., Union Banka, Vakufska Banka, Volskbank B.L. and Volskbank BH).

The sum of the total assets of these 26 banks grows between 2008 and 2010, from 10,280 million EUR to 10,497 million EUR. The median value of assets amounted 147, 152 and 176 million EUR in 2008, 2009 and 2010 respectfully. As presented earlier the efficiency of the banking sector rises in the observed period according to the five-ratio DEA model.

Table 5

Comparison of efficiency scores between FBH and RS banks

\begin{tabular}{|c|c|c|c|c|}
\hline Bank & Entity & $\theta 2008$ & $\theta 2009$ & $\theta 2010$ \\
\hline Bor Banka & $\mathrm{FBH}$ & 0.93 & 0.93 & 1.00 \\
\hline Hyро & $\mathrm{FBH}$ & 0.35 & 0.71 & 0.59 \\
\hline I.K banka Zenica & $\mathrm{FBH}$ & 1.00 & 0.92 & 1.00 \\
\hline Intesa San Paolo & $\mathrm{FBH}$ & 0.55 & 0.85 & 0.93 \\
\hline KIB Velika Kladusa & $\mathrm{FBH}$ & 0.91 & 1.00 & 1.00 \\
\hline Moja Banka & $\mathrm{FBH}$ & 0.33 & 0.52 & 0.63 \\
\hline NLB & $\mathrm{FBH}$ & 0.96 & 0.80 & 0.80 \\
\hline Privredna banka & $\mathrm{FBH}$ & 1.00 & 0.95 & 0.82 \\
\hline ProCredit Bank & $\mathrm{FBH}$ & 1.00 & 1.00 & 1.00 \\
\hline Raiffeisen Bank & $\mathrm{FBH}$ & 0.80 & 0.84 & 0.86 \\
\hline Sparkasse & $\mathrm{FBH}$ & 0.37 & 0.66 & 0.93 \\
\hline Turkish Ziraat & $\mathrm{FBH}$ & 0.97 & 1.00 & 0.96 \\
\hline UniCredit Bank & $\mathrm{FBH}$ & 1.00 & 1.00 & 1.00 \\
\hline Union Banka & $\mathrm{FBH}$ & 0.54 & 0.80 & 0.72 \\
\hline Vakufska Banka & $\mathrm{FBH}$ & 0.67 & 0.75 & 0.91 \\
\hline Volksbank BH & $\mathrm{FBH}$ & 0.75 & 0.85 & 0.83 \\
\hline Balkan Investment Bank & RS & 0.85 & 0.95 & 0.76 \\
\hline Bobar Banka & RS & 0.38 & 0.82 & 0.99 \\
\hline Hyро B.L & RS & 0.71 & 0.81 & 0.67 \\
\hline Komercijalna Banka & RS & 0.51 & 0.83 & 0.90 \\
\hline MF Banka & RS & 0.38 & 0.30 & 1.00 \\
\hline NLB Razvojna & RS & 1.00 & 0.71 & 1.00 \\
\hline Nova Banka & RS & 0.60 & 1.00 & 1.00 \\
\hline Pavlović International & RS & 0.90 & 0.77 & 1.00 \\
\hline Unicredit Bank B.L & RS & 0.70 & 0.83 & 1.00 \\
\hline Volksbank B.L & RS & 0.79 & 0.82 & 1.00 \\
\hline Average efficiency & & 0.73 & 0.82 & 0.90 \\
\hline Average efficiency for FBH & & 0.76 & 0.85 & 0.87 \\
\hline Average efficiency for RS & & 0.68 & 0.79 & 0.92 \\
\hline
\end{tabular}

Source: Author's calculations

In order to compare the results to the ones gained by Chatzoglou et al. (2010) and answer a question whether large banks are more efficient than smaller ones, separate average efficiencies for large and small banks were calculated. As presented in the next table, the efficiency factors between large and small banks were relatively equalled in 2008 and 2009 
showing no efficiency difference between the two groups of banks differentiated by their size (the asset values are given in million EUR). The difference however emerges in 2010 were small banks had a higher average efficiency (0.91) compared to the efficiency of large banks (0.84). It can be concluded that, unlike the results obtained in the Greek sample of banks (Chatzoglou et al. 2010), where large banks seem to be more efficient, the five-ratio model applied on the Bosnian banking market shows that in one out of the three observed periods, small banks are more efficient.

Since the Bosnian banking market is legally, politically and financially divided into two parts or two entities, a logical question is imposed. Since different banks are registered in one of the two entities, it was tested whether there is a difference in profitability and efficiency between banks registered in FBH and RS. The next table gives a comparative overview of the DEA efficiency ratios between the two groups of banks.

Average efficiency ratios have been calculated separately for FBH based and RS based banks. The five-ratio DEA model shows differences in efficiencies between banks registered in the two entities. Banks in FBH were more efficient than banks registered in RS in 200810.76 for FBH and 0.68 for RS) as well as in 2009 (0.85 for FBH and 0.78 for RS). The results have changed in 2010 with RS banks taking the overall lead with a much higher efficiency than in previous two years. The average efficiency ratio for RS banks in 2010 was 0.93 while for banks in FBH it amounted 0.87 . The significantly improved result in RS in 2010 is mostly related to a significant profitability improvement in MF bank which had one of the lowest rankings in 2008 and 2009 and jet receiving the highest efficiency score in 2010.

\section{Discussion and conclusion}

The main contribution of this research is in the fact that DEA method has been applied for the first time on the banking market data from BH. Bosnia and Herzegovina current are a transitional country, with an underdeveloped financial market, whereas the results of such research can benefit from not only the banking but for the whole financial market and the economy in total, through the detection of financial and operational inefficiencies and proper following remedial actions. Apart from the ranking of the banks performed by the competent banking agencies in $\mathrm{BH}$, this research brings a new insight into a ranking of banks from the financial performance aspect. The main contribution of the research is the fact that the total banking sector has been screened in the study, enabling the generalisation of the results and findings. The financial ratios used to construct the efficiency ratios are based on the previous research in this area.

Possible limitations can be in the inaccurate data reported in the financial statements by the banks that can give misleading results and their interpretations. This research aimed at observing the performance data of the banking sector in Bosnia and Herzegovina. A model used five financial ratios (ROA, ROE, NIM, I/EFF and P/L). Since the study covered the total banking sector of Bosnia and Herzegovina, with an exclusion of only three banks which do not satisfy the minimum requirements of the study, the results and the findings can be generalised for the whole market of Bosnia and Herzegovina. Since no such research has been conducted on the Bosnian banking market the results of this research give a unique insight into the efficiency of the banking efficiency in Bosnia and Herzegovina.

The main research questions are successfully answered. A country-wise efficiency ranking of banks was constructed based on DEA results for the three consecutive years, based on their financial performances. An overview of the development of the whole banking sector of Bosnia and Herzegovina has been assessed by the five-ratio DEA model. Previous research often used four-ratio DEA models (Alam et al. 2011; Shanling Li et al. 2001).

Another research question regarding the possible efficiency differences between banks of different size in Bosnia and Herzegovina has been successfully answered. Banks having assets amounting over 511.291 EUR are regarded as large banks. According to the results obtained from the DEA analysis, their financial performance was more efficient in 2008 and 2009 than in small banks, with booked assets bellow 511.291 EUR, similar to the results given by Spathis et al. (2002), Chatzoglou et al. (2010). Small banks however were more efficient in 2010, similar to the results given by Ramadan et al. (2011). 
Aligned with the constitutional, legal and economic structure of $\mathrm{BH}$, and its financial system, separate bank rankings were constructed for FBH and for RS. Average efficiencies of the banking sectors of the two entities were compared, as FBH banks were more efficient in 2008 and 2009, while RS banks showed better overall results in 2010.

The results of the study can be used by bank managers to assess the performance of their banks from another aspect. Observing financial ratios separately can lead ti incomplete and inappropriate conclusion for managers. Comparing the achieved results to the results of the other banks which are considered as competition can also be useful to managers.

The most valuable practical implications of the findings are in the provided feasible targets, for all of the three observed years. Feasible targets represent the values of the bank financial ratios which should be reached if a bank is willing to achieve high efficiency. It is calculated for each bank and for each of the financial ratios used in the analysis.

This research can be regarded as a theory and practice orientated, since it applies a theoretical DEA method and practical financial panel data of banks operating in $\mathrm{BH}$. The possible recommendation for future research would be aimed at applying other statistical methods, such as factor analysis or cluster analysis to classify banks operating in BH into different groups based on their specific characteristics, which could be financial and non/financial. DEA method can also be used to compare other participants of the financial and real sector.

\section{References}

1. Alam, H.M., Raza, A., Akram, M. (2011), "A Financial Performance Comparison of Public Vs Private Banks: The Case of Commercial Banking Sector of Pakistan", International Journal of Business \& Social Science, Vol. 2, No. 11, pp. 56-64.

2. Alper, D., Anbar, A. (2011), "Bank Specific and Macroeconomic Determinants of Commercial Bank Profitability: Empirical Evidence from Turkey", Business \& Economics Research Journal, Vol. 2, No. 2, pp. 139-152.

3. Banker, R.D., Charnes, A., Cooper, W. W. (1984), "Some Models for Estimating Technical and Scale Inefficiencies in Data Envelopment Analysis", Management Science, Vol. 30, No. 9, pp. 1078-1092.

4. Berg, S.A., Gørsund, F.R., Jansen, E.S. (1991), "Technical Efficiency of Norwegian Banks: The Non-Parametric Approach to Efficiency Measurement", Journal of Productivity Analysis, Vol. 2, No. 2, pp. 127-142.

5. Casu, B., Girardone, C., Molyneux, P. (2006), Introduction to banking, Pearson Education.

6. Charnes, A., Cooper, W. W. \& Rhodes, E. (1978), „Measuring the efficiency of decision making units", European Journal of Operational Research, Vol. 2, No. 6, pp. 429-444.

7. Chatzoglou, P.D., Diamantidis A.D., Vraimaki E., Polychrou E., Chatzitheodorou K. (2010), "Banking productivity: an overview of the Greek banking system", Managerial Finance, Vol. 36, No. 12, pp. 1007-1027.

8. Chen, T.-Y., Yeh, T.-L. (2000), "A Measurement of Bank Efficiency, Ownership and Productivity Changes in Taiwan", Service Industries Journal, Vol. 20, No. 1, pp. 95-109.

9. Cooper, William W., (2010), Handbook on Data Envelopment Analysis, Springer.

10. Derbali, A. (2011), "Determinants of banking profitability before and during the financial crisis of 2007: The case of Tunisian banks", Interdisciplinary Journal of Contemporary Research in Business, Vol. 3, No. 3, pp. 1256-1269.

11. Fakhri, G., Menacere, K. \& Pegum, R., (2010), Organizational Specificities That Affect The Use Of Corporate Performance Measurements Process In The Banking Sector. Journal of Performance Management, Vol. 23, No. 3, pp. 5-22.

12. Feroz, E.H., Kim, S., Raab, R.L. (2003), "Financial statement analysis: A data envelopment analysis approach", Journal of the Operational Research Society, Vol. 54, No. 1, pp. 48.

13. Gaganis, C. et al. (2009), "Estimating and analyzing the efficiency and productivity of bank branches: Evidence from Greece", Managerial Finance, Vol. 35, No. 2, pp. 202-218.

14. Gaganis, C., Pasiouras, F. (2009), "Efficiency in the Greek Banking Industry: A Comparison of Foreign and Domestic Banks", International Journal of the Economics of Business, Vol. 16, No. 2, pp. 221-237. 
15. Garcia-Sánchez, I.M. (2007), "Efficiency and effectiveness of Spanish football teams: a three-stage-DEA approach", Central European Journal of Operations Research, Vol. 15, No. 1, pp. 21-45.

16. Goddard, J., Molyneux, P., Wilson, J.O.S. (2004), "The profitability of European banks: a cross-sectional and dynamic panel analysis", Manchester School, Vol. 72, No. 3, pp. 363381.

17. Halkos, G. (2004), "Efficiency measurement of the Greek commercial banks with the use of financial ratios: a data envelopment analysis approach", Management Accounting Research, Vol. 15, No. 2, pp. 201-224.

18. Ho, C.-T., Wu, Y.-S. (2006), "Benchmarking performance indicators for banks", Benchmarking: An International Journal, Vol.13, No. 1/2, pp. 147-159.

19. Ho, C.-T. (2006), "Measuring bank operations performance: an approach based on Grey Relation Analysis", Journal of the Operational Research Society, Vol. 57, No. 4, pp. 337349.

20. Jemric, I., Vujcic, B. (2002), "Efficiency of Banks in Croatia: A Dea Approach", available at: http://papers.ssrn.com/sol3/papers.cfm?abstract_id=1673690 / ( 25 November 201 1].

21. Kapor, P. (2005), Bankarstvo sa osnovama bankarskog poslovanja i medjunarodnim bankarstvom, Megatrend univerzitet primjenjenih nauka, Beograd.

22. Kosmidou, K., Zopounidis, C. (2008), "Measurement of Bank Performance in Greece", South-Eastern Europe Journal of Economics, Vol. 1, pp. 79-95.

23. Keh, H.T., Chu, S., XU, J. (2006), "Efficiency, effectiveness and productivity of marketing in services", European Journal of Operational Research, Vol. 170, No. 1, pp. 265-276.

24. Kosmidou, K. et al. (2006), "Assessing Performance Factors in the UK Banking Sector: A Multicriteria Methodology", Central European Journal of Operations Research, Vol. 14, No. 1, pp. 25-44.

25. Koçak, H. (2011), "Efficiency Examination of Turkish Airports with DEA Approach", International Business Research, Vol. 4, No. 2, pp. 204-212.

26. Kumar, S., Gulati, R. (2010), "Measuring efficiency, effectiveness and performance of Indian public sector banks", International Journal of Productivity and Performance Management, Vol. 59, No. 1, pp. 51-74.

27. Mostafa, M. (2007), "Benchmarking top Arab banks' efficiency through efficient frontier analysis", Industrial Management \& Data Systems, Vol. 107, No. 6, pp. 802-823.

28. Ozcan, Y.A., McCue, M.J. (1996), "Development of a financial performance index for hospitals: DEA approach", Journal of the Operational Research Society, Vol. 47, No. 1, pp. 18.

29. Ozkan-Gunay, E.N., Tektas, A. (2006), "Efficiency Analysis of the Turkish Banking Sector in Precrisis and Crisis Period: A DEA Approach", available at: http://papers.ssrn.com/sol3/papers.cfm?abstract_id=1095583 / (23 November 2011).

30. Pejic-Bach, M., Simicevic, V. (2006), "Financial Structure and the Profitability of Croatian Banks", available at: http://www.wseas.us/e-library/conferences/2006cavtat/papers/528105.pdf / ( 23 November 2011).

31. Ramadan, I.Z., Kilani, Q.A., Kaddumi, T.A. (2011), "Determinants of Bank Profitability: Evidence from Jordan", International Journal of Academic Research, Vol. 3, No. 4, pp. 180-191.

32. Ramanathan, R. (2007), "Performance of banks in countries of the Gulf Cooperation Council", International Journal of Productivity and Performance Management, Vol. 56, No. 2, pp. 137-154.

33. Rose, P.S. (2001), Commercial bank management, McGraw-Hill/Irwin, Boston.

34. Shanling Li, Feng Liu, Whitmore, G.A. (2001), "Comparative Performance of Chinese Commercial Banks: Analysis, Findings and Policy Implications", Review of Quantitative Finance \& Accounting, Vol. 16, No. 2, pp.149-170.

35. Spathis, C., Kosmidou, K., Doumpos, M. (2002), "Assessing Profitability Factors in the Greek Banking System: A Multicriteria Methodology", International Transactions in Operational Research, Vol. 9, No. 5, pp. 517-530.

36. Sultan, J., Bilal, M., Abbas, Z. (2011), "Performance measurement by Data Envelopment Analysis (DEA): A study of banking sector in Pakistan", Interdisciplinary Journal of Contemporary Research in Business, Vol. 2, No. 12, pp. 229-249. 
37. Šarlija, N., Harc, M. (2012). "The impact of liquidity on the capital structure: a case study of Croatian firms", Business Systems Research, Vol. 3, No. 1, pp. 30-36.

38. Talluri, S. (2000), "Data Envelopment Analysis: Models and Extensions", available at: http://www.decisionsciences.org/decisionline/Vol31/31_3/31_3pom.pdf / (10 November 2011).

39. Tsolas, I.E., 2010. Modeling bank branch profitability and effectiveness by means of DEA. International Journal of Productivity and Performance Management, Vol. 59, No. 5, pp. 432-451.

40. Ulucan, A. (2011), "Measuring the Efficiency of Turkish Universities Using Measure-Specific Data Envelopment Analysis", Sosyoekonomi, Vol. 7, No. 1, pp. 181-196

41. Vojvodic Rosenzweig, V., Volarevic, H., Varovic, M. (2012). "Profitability as a business goal: the multicriteria approach to the ranking of the five largest Croatian banks", Business Systems Research, Vol. 3, No. 1, pp. 37-48.

42. Van Horne, J.C., Wachowicz J.M. (2001), Fundamentals of Financial Management, Prentice-Hall.

43. Zhu, J. (2003), Quantitative models for performance evaluation and benchmarking: data envelopment analysis with spreadsheets and DEA Excel Solver, Springer.

\section{Data Sources}

1. Abbreviated Audit Report of Banks in the Republika Srpska (2009), available at: http://www.abrs.ba/publikacije/RevizBankeRS31122009.pdf / (10 November 2011).

2. Abbreviated Audit Report of Banks in the Republika Srpska (2010), available at: http://www.abrs.ba/publikacije/RevizBankeRS31122010.pdf / (10 November 2011).

3. Abbreviated Audit Report of Banks in the Republika Srpska (2008), available at: http://www.abrs.ba/publikacije/RevizBankeRS31 122008.pdf / (10 November 2011).

4. CBBH Annual Report (2010), available at: http://www.cbbh.ba/files/godisnji_izvjestaji/2010/Gl_2010_en.pdf/(10 November 2011).

5. CBBH Annual Report (2009), available at: http://www.cbbh.ba/files/godisnii_izvjestaji/2009/Gl_2009_en.pdf / (10 November 2011).

6. CBBH Annual Report (2008), available at: http://www.cbbh.ba/files/godisnji_izvjestaji/2008/cbbh_annual_report_2008_en.pdf / (10 November 2011).

7. Condensed Reports of External Auditors on Financial Statements of Banks in the Federation of Bosnia and Herzegovina (2008), available at: http://www.fba.ba/images/documents_archive/publikacije_68_3.pdf / (05 Novem 2011).

8. Condensed Reports of External Auditors on Financial Statements of Banks in the Federation of Bosnia and Herzegovina (2009), available at: http://www.fba.ba/index.php?page=article\&id=296 / (05 November 2011).

9. Condensed Reports of External Auditors on Financial Statements of Banks in the Federation of Bosnia and Herzegovina (2010), available at: http://www.fba.ba/images/Publikacije Banke/BF_2010.pdf / (05 November 2011).

10. Information on Banking System of the Federation of Bosnia and Herzegovina as of 31.12.2008. (2008), available at:

http://www.fba.ba/images/Publikacije_Banke/Informacija_bank_31122010_eng.pdf (05 November 2011 ).

11. Information on Banking System of the Federation of Bosnia and Herzegovina as of 31.12.2009. (2009), available at: http://www.fba.ba/images/documents_archive/publikacije_71_3.pdf / (05 Novem 2011).

12. Information on Banking System of the Federation of Bosnia and Herzegovina as of 31.12.2010. (2010), available at: http://www.fba.ba/images/documents_archive/publikacije_66_3.pdf / (05 Novem 2011).

13. Report on Condition of Banking system of Republika Srpska (2008), available at: http://www.abrs.ba/publikacije/end2008.pdf / (05 November 2011).

14. Report on Condition of Banking system of Republika Srpska (2009), available at: http://www.abrs.ba/publikacije/end2009.pdf / (05 November 2011).

15. Report on Condition of Banking system of Republika Srpska (2010), available at: http://www.abrs.ba/publikacije/end2010.pdf.pdf / (05 November 2011). 


\section{Appendices}

\section{Appendix 1}

Five ratios calculation for 2008

\begin{tabular}{|c|c|c|c|c|c|c|c|}
\hline Bank & Entity & Size & $\begin{array}{l}R O E \\
2008\end{array}$ & $\begin{array}{l}\text { ROA } \\
2008\end{array}$ & $\begin{array}{l}\text { NIM } \\
2008\end{array}$ & $\begin{array}{l}\text { l/EFF } \\
2008\end{array}$ & $\begin{array}{c}P / L \\
2008\end{array}$ \\
\hline Balkan Investment Bank & RS & $S$ & 0.034 & 0.004 & 0.053 & 1.081 & $2,810.77$ \\
\hline Bobar Banka & RS & S & 0.020 & 0.002 & 0.024 & 1.033 & $1,085.76$ \\
\hline Bor Banka & $\mathrm{FBH}$ & S & 0.024 & 0.010 & 0.041 & 1.230 & $11,623.55$ \\
\hline Нуро & $\mathrm{FBH}$ & L & -0.083 & -0.007 & 0.024 & 0.849 & $-12,999.76$ \\
\hline Hуро B.L & RS & L & 0.069 & 0.006 & 0.025 & 1.168 & $9,732.02$ \\
\hline I.K banka Zenica & $\mathrm{FBH}$ & S & 0.079 & 0.024 & 0.054 & 1.388 & $10,374.53$ \\
\hline Intesa San Paolo & $\mathrm{FBH}$ & $L$ & 0.030 & 0.004 & 0.033 & 1.068 & $3,779.13$ \\
\hline KIB Velika Kladusa & $\mathrm{FBH}$ & S & 0.050 & 0.018 & 0.053 & 1.259 & $7,471.08$ \\
\hline Komercijalna Banka & RS & S & 0.025 & 0.002 & 0.033 & 1.078 & $2,287.39$ \\
\hline MF Banka & RS & S & -0.096 & -0.056 & 0.031 & 0.387 & $-29,178.19$ \\
\hline Moja Banka & $\mathrm{FBH}$ & S & -0.342 & -0.069 & 0.027 & 0.378 & $-26,498.38$ \\
\hline NLB & $\mathrm{FBH}$ & S & 0.154 & 0.012 & 0.037 & 1.229 & $9,372.82$ \\
\hline NLB Razvojna & RS & $L$ & 0.188 & 0.013 & 0.032 & 1.077 & $15,478.72$ \\
\hline Nova Banka & RS & S & 0.061 & 0.005 & 0.032 & 1.076 & $3,956.80$ \\
\hline Pavlović International & RS & S & 0.075 & 0.014 & 0.051 & 1.091 & 4,422.05 \\
\hline Privredna banka & $\mathrm{FBH}$ & S & 0.173 & 0.048 & 0.026 & 1.411 & $14,383.60$ \\
\hline ProCredit Bank & $\mathrm{FBH}$ & S & 0.005 & 0.000 & 0.083 & 1.005 & 120.34 \\
\hline Raiffeisen Bank & $\mathrm{FBH}$ & $L$ & 0.099 & 0.008 & 0.033 & 1.191 & $10,350.53$ \\
\hline Sparkasse & $\mathrm{FBH}$ & S & -0.089 & -0.011 & 0.027 & 0.812 & $-7,973.04$ \\
\hline Turkish Ziraat & $\mathrm{FBH}$ & S & 0.029 & 0.013 & 0.061 & 1.170 & $6,773.87$ \\
\hline UniCredit Bank & $\mathrm{FBH}$ & L & 0.114 & 0.012 & 0.036 & 1.238 & $13,886.59$ \\
\hline Unicredit Bank B.L & RS & S & 0.013 & 0.001 & 0.034 & 0.976 & 846.60 \\
\hline Union Banka & $\mathrm{FBH}$ & S & 0.013 & 0.003 & 0.038 & 1.043 & $1,741.34$ \\
\hline Vakufska Banka & $\mathrm{FBH}$ & S & 0.029 & 0.009 & 0.043 & 1.157 & $3,762.06$ \\
\hline Volksbank B.L & RS & S & 0.044 & 0.005 & 0.028 & 1.114 & $5,169.33$ \\
\hline Volksbank BH & $\mathrm{FBH}$ & S & 0.069 & 0.007 & 0.035 & 1.172 & $8,575.11$ \\
\hline Minimum & & & -0.342 & -0.069 & 0.024 & 0.378 & $-29,178.19$ \\
\hline Maximum & & & 0.188 & 0.048 & 0.083 & 1.411 & $15,478.72$ \\
\hline Mean & & & 0.030 & 0.003 & 0.038 & 1.065 & $2,744.41$ \\
\hline Std. Deviation & & & 0.103 & 0.022 & 0.014 & 0.242 & $11,037.56$ \\
\hline
\end{tabular}

Source: Author's calculations

\section{Appendix 2}

Five ratios calculation for 2009

\begin{tabular}{|c|c|c|c|c|c|c|c|}
\hline Bank & Entity & Size & $\begin{array}{l}\text { ROE } \\
2009\end{array}$ & $\begin{array}{l}\text { ROA } \\
2009\end{array}$ & $\begin{array}{l}\text { NIM } \\
2009\end{array}$ & $\begin{array}{l}\text { 1/EFF } \\
2009\end{array}$ & $\begin{array}{c}P / L \\
2009\end{array}$ \\
\hline Balkan Investment Bank & RS & $S$ & 0.003 & 0.000 & 0.051 & 0.961 & 261.60 \\
\hline Bobar Banka & RS & S & 0.041 & 0.005 & 0.038 & 1.068 & $3,021.05$ \\
\hline Bor Banka & $\mathrm{FBH}$ & S & 0.022 & 0.008 & 0.037 & 1.200 & $9,433.99$ \\
\hline Нуро & $\mathrm{FBH}$ & $L$ & -0.113 & -0.009 & 0.037 & 0.844 & $-17,600.65$ \\
\hline Нуро B.L & RS & $L$ & 0.034 & 0.003 & 0.037 & 1.041 & $4,706.20$ \\
\hline I.K banka Zenica & $\mathrm{FBH}$ & S & 0.037 & 0.010 & 0.041 & 1.201 & $5,145.32$ \\
\hline Intesa San Paolo & $\mathrm{FBH}$ & L & 0.033 & 0.003 & 0.035 & 1.072 & $3,996.89$ \\
\hline
\end{tabular}




\begin{tabular}{|c|c|c|c|c|c|c|c|}
\hline KIB Velika Kladusa & FBH & $\mathrm{S}$ & 0.055 & 0.020 & 0.046 & 1.311 & $8,075.53$ \\
\hline Komercijalna Banka & RS & S & 0.011 & 0.001 & 0.033 & 1.011 & $870 ., 81$ \\
\hline MF Banka & RS & $S$ & -0.321 & -0.174 & 0.021 & 0.134 & $76,148.44$ \\
\hline Moja Banka & $\mathrm{FBH}$ & S & -0.476 & -0.059 & 0.034 & 0.473 & $-28,871.15$ \\
\hline NLB & $\mathrm{FBH}$ & S & 0.037 & 0.003 & 0.032 & 1.054 & $2,513.26$ \\
\hline NLB Razvojna & RS & L & 0.086 & 0.006 & 0.024 & 0.851 & $7,036.28$ \\
\hline Nova Banka & RS & $S$ & 0.158 & 0.014 & 0.028 & 1.233 & $14,582.08$ \\
\hline Pavlović International & RS & S & 0.010 & 0.002 & 0.037 & 0.973 & 564.76 \\
\hline Privredna banka & $\mathrm{FBH}$ & S & 0.067 & 0.016 & 0.023 & 1.235 & $6,542.02$ \\
\hline ProCredit Bank & $\mathrm{FBH}$ & S & -0.451 & -0.047 & 0.075 & 0.681 & $-12,306.73$ \\
\hline Raiffeisen Bank & $\mathrm{FBH}$ & L & 0.026 & 0.002 & 0.029 & 1.052 & $2,934.84$ \\
\hline Sparkasse & $\mathrm{FBH}$ & S & -0.081 & -0.010 & 0.031 & 0.846 & $-7,779.92$ \\
\hline Turkish Ziraat & $\mathrm{FBH}$ & S & 0.013 & 0.006 & 0.053 & 1.076 & $3,034.16$ \\
\hline UniCredit Bank & $\mathrm{FBH}$ & L & 0.093 & 0.010 & 0.036 & 1.205 & $12,683.48$ \\
\hline Unicredit Bank B.L & RS & S & 0.033 & 0.004 & 0.040 & 0.928 & $2,386.74$ \\
\hline Union Banka & $\mathrm{FBH}$ & S & 0.013 & 0.004 & 0.029 & 1.052 & $1,791.01$ \\
\hline Vakufska Banka & FBH & S & -0.025 & -0.006 & 0.038 & 0.899 & $-2,949.06$ \\
\hline Volksbank B.L & RS & S & 0.054 & 0.008 & 0.036 & 0.995 & $6,875.12$ \\
\hline Volksbank BH & FBH & S & 0.042 & 0.005 & 0.034 & 1.112 & $5,700.84$ \\
\hline Minimum & & & -0.476 & -0.174 & 0.021 & 0.134 & $-76,148.44$ \\
\hline Maximum & & & 0.158 & 0.020 & 0.075 & 1.311 & $14,582.08$ \\
\hline Mean & & & -0.023 & -0.007 & 0.037 & 0.981 & $-1,673.08$ \\
\hline Std. Deviation & & & 0.155 & 0.038 & 0.011 & 0.251 & $17,773.60$ \\
\hline
\end{tabular}

Source: Author's calculations

Appendix 3

Five ratios calculation for 2010

\begin{tabular}{|c|c|c|c|c|c|c|c|}
\hline Bank & Entity & Size & $\begin{array}{l}\text { ROE } \\
2010\end{array}$ & $\begin{array}{l}R O A \\
2010\end{array}$ & $\begin{array}{l}\text { NIM } \\
2010\end{array}$ & $\begin{array}{l}\text { 1/EFF } \\
2010\end{array}$ & $\begin{array}{c}P / L \\
2010\end{array}$ \\
\hline Balkan Investment Bank & RS & $\mathrm{s}$ & 0.030 & 0.005 & 0.028 & 0.994 & $2,902.79$ \\
\hline Bobar Banka & RS & $S$ & 0.040 & 0.006 & 0.042 & 1.056 & $3,743.85$ \\
\hline Bor Banka & $\mathrm{FBH}$ & $S$ & 0.037 & 0.010 & 0.034 & 1.322 & $14,911.37$ \\
\hline Нуро & $\mathrm{FBH}$ & L & -0.936 & -0.075 & 0.032 & 0.402 & $-118,861.40$ \\
\hline Нуро B.L & RS & L & -0.215 & -0.030 & 0.035 & 0.607 & $-44,925.17$ \\
\hline I.K banka Zenica & $\mathrm{FBH}$ & $S$ & 0.042 & 0.012 & 0.036 & 1.259 & $5,963.25$ \\
\hline Intesa San Paolo & $\mathrm{FBH}$ & L & 0.054 & 0.005 & 0.038 & 1.111 & $6,840.98$ \\
\hline KIB Velika Kladusa & $\mathrm{FBH}$ & S & 0.046 & 0.015 & 0.025 & 1.281 & $6,860.58$ \\
\hline Komercijalna Banka & RS & S & 0.008 & 0.002 & 0.037 & 1.028 & $2,077.66$ \\
\hline MF Banka & RS & $S$ & 0.042 & 0.026 & 0.009 & 0.451 & $12,058.16$ \\
\hline Moja Banka & $\mathrm{FBH}$ & $S$ & -0.354 & -0.057 & 0.027 & 0.479 & $-29,080.19$ \\
\hline NLB & $\mathrm{FBH}$ & $S$ & 0.010 & 0.001 & 0.031 & 1.014 & 708.70 \\
\hline NLB Razvojna & RS & L & 0.122 & 0.010 & 0.031 & 1.615 & $10,981.88$ \\
\hline Nova Banka & RS & S & 0.114 & 0.012 & 0.028 & 1.122 & $12,231.68$ \\
\hline Pavlović International & RS & $S$ & 0.067 & 0.011 & 0.041 & 1.079 & $4,396.72$ \\
\hline Privredna banka & $\mathrm{FBH}$ & $S$ & 0.039 & 0.007 & 0.029 & 1.102 & $3,596.06$ \\
\hline ProCredit Bank & $\mathrm{FBH}$ & S & -0.211 & -0.021 & 0.054 & 0.801 & $-6,712.21$ \\
\hline Raiffeisen Bank & $\mathrm{FBH}$ & L & 0.021 & 0.002 & 0.036 & 1.038 & $2,470.87$ \\
\hline Sparkasse & $\mathrm{FBH}$ & $S$ & 0.024 & 0.002 & 0.038 & 1.045 & $2,338.06$ \\
\hline Turkish Ziraat & $\mathrm{FBH}$ & $S$ & 0.008 & 0.003 & 0.041 & 1.044 & $1,765.69$ \\
\hline
\end{tabular}




\begin{tabular}{|c|c|c|c|c|c|c|c|}
\hline UniCredit Bank & FBH & $L$ & 0.108 & 0.010 & 0.035 & 1.212 & $13,745.78$ \\
\hline Unicredit Bank B.L & RS & S & 0.016 & 0.002 & 0.045 & 0.965 & $1,167.93$ \\
\hline Union Banka & $\mathrm{FBH}$ & S & 0.029 & 0.008 & 0.023 & 1.082 & $3,851.79$ \\
\hline Vakufska Banka & $\mathrm{FBH}$ & S & 0.005 & 0.001 & 0.040 & 1.021 & 605.73 \\
\hline Volksbank B.L & RS & S & 0.083 & 0.012 & 0.040 & 1.271 & $11,562.56$ \\
\hline Volksbank BH & $\mathrm{FBH}$ & S & 0.017 & 0.002 & 0.034 & 1.042 & $2,401.56$ \\
\hline Minimum & & & -0.936 & -0.075 & 0.009 & 0.402 & $-118,861.40$ \\
\hline Maximum & & & 0.122 & 0.026 & 0.054 & 1.615 & $14,911.37$ \\
\hline Mean & & & -0.029 & -0.001 & 0.034 & 1.017 & $-2,784.44$ \\
\hline Std. Deviation & & & 0.213 & 0.022 & 0.008 & 0.278 & $26,849.22$ \\
\hline
\end{tabular}

Source: Author's calculations

Appendix 4

Feasible targets 2008

\begin{tabular}{|c|c|c|c|c|c|}
\hline 2008 & $R O E$ & $R O A$ & NIM & $1 / E F F$ & $P / L$ \\
\hline Balkan Investment Bank & $\begin{array}{c}3.41 \% \\
(5.73 \%)\end{array}$ & $\begin{array}{c}0.45 \% \\
(1.68 \%)\end{array}$ & $\begin{array}{c}5.30 \% \\
(6.24 \%)\end{array}$ & $\begin{array}{c}1.0814 \\
(1.2744)\end{array}$ & $\begin{array}{c}2,810.77 \\
(\mathbf{7}, 329.48)\end{array}$ \\
\hline Bobar Banka & $\begin{array}{c}1.98 \% \\
(7.05 \%)\end{array}$ & $\begin{array}{c}0.19 \% \\
(0.66 \%)\end{array}$ & $\begin{array}{c}2.41 \% \\
(5.67 \%)\end{array}$ & $\begin{array}{l}1.0335 \\
(1.1188)\end{array}$ & $\begin{array}{c}1,085.76 \\
(7,776.00)\end{array}$ \\
\hline Bor Banka & $\begin{array}{c}2.42 \% \\
(12.86 \%)\end{array}$ & $\begin{array}{c}0.99 \% \\
(1.85 \%)\end{array}$ & $\begin{array}{c}4.10 \% \\
(4.38 \%)\end{array}$ & $\begin{array}{c}1.2295 \\
(1.2463)\end{array}$ & $\begin{array}{r}11,623.55 \\
(12,709.37)\end{array}$ \\
\hline Нуро & $\begin{array}{l}-8.34 \% \\
(4.69 \%)\end{array}$ & $\begin{array}{c}-0.65 \% \\
(0.47 \%)\end{array}$ & $\begin{array}{c}2.44 \% \\
(6.45 \%)\end{array}$ & $\begin{array}{c}0.8494 \\
(1.0947)\end{array}$ & $\begin{array}{l}-12,999.76 \\
(5,445.13)\end{array}$ \\
\hline Нуро B.L & $\begin{array}{c}6.86 \% \\
(17.48 \%)\end{array}$ & $\begin{array}{c}0.56 \% \\
(1.26 \%)\end{array}$ & $\begin{array}{c}2.52 \% \\
(3.30 \%)\end{array}$ & $\begin{array}{c}1.1682 \\
(1.1078)\end{array}$ & $\begin{array}{c}9,732.02 \\
(15,139.00)\end{array}$ \\
\hline I.K banka Zenica & $\begin{array}{c}7.94 \% \\
(7.94 \%)\end{array}$ & $\begin{array}{c}2.37 \% \\
(2.37 \%)\end{array}$ & $\begin{array}{c}5.40 \% \\
(5.40 \%)\end{array}$ & $\begin{array}{c}1.3875 \\
(1.3875)\end{array}$ & $\begin{array}{c}10,374.53 \\
(10,374.53)\end{array}$ \\
\hline Intesa San Paolo & $\begin{array}{c}3.03 \% \\
(6.81 \%)\end{array}$ & $\begin{array}{c}0.36 \% \\
(1.59 \%)\end{array}$ & $\begin{array}{c}3.34 \% \\
(5.74 \%)\end{array}$ & $\begin{array}{c}1.0675 \\
(1.2684)\end{array}$ & $\begin{array}{c}3,779.13 \\
(8,583.68)\end{array}$ \\
\hline KIB Velika Kladusa & $\begin{array}{c}5.02 \% \\
(7.04 \%)\end{array}$ & $\begin{array}{c}1.82 \% \\
(2.00 \%)\end{array}$ & $\begin{array}{c}5.28 \% \\
(5.79 \%)\end{array}$ & $\begin{array}{c}1.2588 \\
(1.3014)\end{array}$ & $\begin{array}{c}7,471.08 \\
(8,478.92)\end{array}$ \\
\hline Komercijalna Banka & $\begin{array}{c}2.49 \% \\
(5.89 \%)\end{array}$ & $\begin{array}{c}0.23 \% \\
(1.01 \%)\end{array}$ & $\begin{array}{c}3.34 \% \\
(6.11 \%)\end{array}$ & $\begin{array}{c}1.0782 \\
(1.1727)\end{array}$ & $\begin{array}{c}2,287.39 \\
(6,971.98)\end{array}$ \\
\hline MF Banka & $\begin{array}{l}-9.62 \% \\
(0.50 \%)\end{array}$ & $\begin{array}{l}-5.58 \% \\
\mathbf{( 0 . 0 4 \% )}\end{array}$ & $\begin{array}{c}3.15 \% \\
(8.25 \%)\end{array}$ & $\begin{array}{c}0.3873 \\
(1.0051)\end{array}$ & $\begin{array}{c}-29,178.19 \\
(157.51)\end{array}$ \\
\hline Moja Banka & $\begin{array}{l}-34.24 \% \\
(0.88 \%)\end{array}$ & $\begin{array}{l}-6.87 \% \\
(0.08 \%)\end{array}$ & $\begin{array}{c}2.69 \% \\
(8.09 \%)\end{array}$ & $\begin{array}{c}0.3781 \\
(1.0131)\end{array}$ & $\begin{array}{c}-26,498.38 \\
(631.07)\end{array}$ \\
\hline NLB & $\begin{array}{c}15.35 \% \\
(16.24 \%)\end{array}$ & $\begin{array}{c}1.17 \% \\
(1.21 \%)\end{array}$ & $\begin{array}{c}3.72 \% \\
(3.79 \%)\end{array}$ & $\begin{array}{c}1.2295 \\
(1.0870)\end{array}$ & $\begin{array}{c}9,372.82 \\
(13,584.38)\end{array}$ \\
\hline NLB Razvojna & $\begin{array}{c}18.82 \% \\
(18.82 \%)\end{array}$ & $\begin{array}{c}1.26 \% \\
(1.26 \%)\end{array}$ & $\begin{array}{c}3.20 \% \\
(3.20 \%)\end{array}$ & $\begin{array}{c}1.0775 \\
(1.0775)\end{array}$ & $\begin{array}{c}15,478.72 \\
(15,478.72)\end{array}$ \\
\hline Nova Banka & $\begin{array}{c}6.12 \% \\
(11.00 \%)\end{array}$ & $\begin{array}{c}0.52 \% \\
(\mathbf{0 . 8 2 \% )}\end{array}$ & $\begin{array}{c}3.19 \% \\
(5.02 \%)\end{array}$ & $\begin{array}{c}1.0762 \\
(1.0849)\end{array}$ & $\begin{array}{c}3,956.80 \\
(9,875.15)\end{array}$ \\
\hline Pavlović International & $\begin{array}{c}7.53 \% \\
(8.34 \%)\end{array}$ & $\begin{array}{c}1.42 \% \\
(1.57 \%)\end{array}$ & $\begin{array}{c}5.14 \% \\
(5.69 \%)\end{array}$ & $\begin{array}{c}1.0914 \\
(1.2083)\end{array}$ & $\begin{array}{c}4,422.05 \\
(\mathbf{8}, \mathbf{4 4 0 . 8 7})\end{array}$ \\
\hline Privredna banka & $\begin{array}{c}17.32 \% \\
(17.32 \%)\end{array}$ & $\begin{array}{c}4.81 \% \\
(4.81 \%)\end{array}$ & $\begin{array}{c}2.64 \% \\
(2.64 \%)\end{array}$ & $\begin{array}{c}1.4108 \\
(1.4108)\end{array}$ & $\begin{array}{r}14,383.60 \\
(14,383.60)\end{array}$ \\
\hline ProCredit Bank & $\begin{array}{c}0.47 \% \\
(0.47 \%)\end{array}$ & $\begin{array}{c}0.04 \% \\
(0.04 \%)\end{array}$ & $\begin{array}{c}8.26 \% \\
(8.26 \%)\end{array}$ & $\begin{array}{c}1.0045 \\
(1.0045)\end{array}$ & $\begin{array}{c}120.34 \\
(120.34)\end{array}$ \\
\hline Raiffeisen Bank & $\begin{array}{c}9.88 \% \\
(14.66 \%)\end{array}$ & $\begin{array}{c}0.82 \% \\
(1.61 \%)\end{array}$ & $\begin{array}{c}3.27 \% \\
(3.95 \%)\end{array}$ & $\begin{array}{c}1.1905 \\
(1.1916)\end{array}$ & $\begin{array}{r}10,350.53 \\
(13,678.57)\end{array}$ \\
\hline Sparkasse & $\begin{array}{c}-8.94 \% \\
(4.02 \%)\end{array}$ & $\begin{array}{c}-1.12 \% \\
(0.40 \%)\end{array}$ & $\begin{array}{c}2.65 \% \\
\text { (6.74\%) }\end{array}$ & $\begin{array}{c}0.8125 \\
(1.0802)\end{array}$ & $\begin{array}{l}-7,973.04 \\
(4,590.24)\end{array}$ \\
\hline Turkish Ziraat & $\begin{array}{c}2.94 \% \\
(5.48 \%)\end{array}$ & $\begin{array}{c}1.34 \% \\
(1.60 \%)\end{array}$ & $\begin{array}{c}6.14 \% \\
(6.34 \%)\end{array}$ & $\begin{array}{c}1.1702 \\
(1.2614)\end{array}$ & $\begin{array}{c}6,773.87 \\
(6,980.68)\end{array}$ \\
\hline UniCredit Bank & $\begin{array}{c}11.39 \% \\
(11.39 \%)\end{array}$ & $\begin{array}{c}1.16 \% \\
(1.16 \%)\end{array}$ & $\begin{array}{c}3.59 \% \\
(3.59 \%)\end{array}$ & $\begin{array}{c}1.2376 \\
(1.2376)\end{array}$ & $\begin{array}{c}13,886.59 \\
(13,886.59)\end{array}$ \\
\hline Unicredit Bank B.L & $1.25 \%$ & $0.14 \%$ & $3.43 \%$ & 0.9759 & 846.60 \\
\hline
\end{tabular}




\begin{tabular}{lccccc}
\hline & $(9.69 \%)$ & $(2.82 \%)$ & $(4.89 \%)$ & $(1.3918)$ & $(11,101.43)$ \\
Union Banka & $1.32 \%$ & $0.35 \%$ & $3.78 \%$ & 1.0432 & $1,741.34$ \\
& $(4.47 \%)$ & $(0.77 \%)$ & $(6.62 \%)$ & $(1.1361)$ & $(5,327.47)$ \\
Vakufska Banka & $2.94 \%$ & $0.88 \%$ & $4.33 \%$ & 1.1570 & $3,762.06$ \\
& $(5.58 \%)$ & $(1.31 \%)$ & $(6.23 \%)$ & $(1.2198)$ & $(6,951.68)$ \\
Volksbank BH & $6.91 \%$ & $0.69 \%$ & $3.48 \%$ & 1.1724 & $8,575.11$ \\
& $(11.73 \%)$ & $(1.91 \%)$ & $(4.54 \%)$ & $(1.2750)$ & $(12,300.26)$ \\
Volksbank B.L & $4.37 \%$ & $0.51 \%$ & $2.82 \%$ & 1.1140 & $5,169.33$ \\
& $(14.25 \%)$ & $(4.01 \%)$ & $(3.55 \%)$ & $(1.4032)$ & $(13,063.47)$ \\
\hline
\end{tabular}

Source: Author's calculations

Appendix 5

Feasible targets 2009

\begin{tabular}{|c|c|c|c|c|c|}
\hline 2009 & ROE & ROA & NIM & $1 / E F F$ & $P / L$ \\
\hline Turkish Ziraat & $\begin{array}{c}1.33 \% \\
(1.33 \%)\end{array}$ & $\begin{array}{c}0.59 \% \\
(0.59 \%)\end{array}$ & $\begin{array}{c}5.31 \% \\
\mathbf{( 5 . 3 1 \% )}\end{array}$ & $\begin{array}{c}1.0756 \\
(1.0756)\end{array}$ & $\begin{array}{c}3.034,16 \\
(3.034,16)\end{array}$ \\
\hline Nova Banka & $\begin{array}{c}15.78 \% \\
(15.78 \%)\end{array}$ & $\begin{array}{c}1.42 \% \\
(1.42 \%)\end{array}$ & $\begin{array}{c}2.77 \% \\
(\mathbf{2 . 7 7 \%})\end{array}$ & $\begin{array}{c}1.2330 \\
(1.2330)\end{array}$ & $\begin{array}{c}14.582,08 \\
(14.582,08)\end{array}$ \\
\hline UniCredit Bank & $\begin{array}{c}9.34 \% \\
(9.34 \%)\end{array}$ & $\begin{array}{c}1.00 \% \\
(1.00 \%)\end{array}$ & $\begin{array}{c}3.59 \% \\
(3.59 \%)\end{array}$ & $\begin{array}{c}1.2052 \\
(1.2052)\end{array}$ & $\begin{array}{c}12.683,48 \\
(12.683,48)\end{array}$ \\
\hline ProCredit Bank & $\begin{array}{c}-45.12 \% \\
(-45.12 \%)\end{array}$ & $\begin{array}{c}-4.70 \% \\
(-4.70 \%)\end{array}$ & $\begin{array}{c}7.52 \% \\
(7.52 \%)\end{array}$ & $\begin{array}{c}0.6814 \\
(\mathbf{0 . 6 8 1 4})\end{array}$ & $\begin{array}{c}-12.306,73 \\
(-12.306,73)\end{array}$ \\
\hline KIB Velika Kladusa & $\begin{array}{c}5.46 \% \\
(5.46 \%)\end{array}$ & $\begin{array}{c}1.98 \% \\
(1.98 \%)\end{array}$ & $\begin{array}{c}4.61 \% \\
(4.61 \%)\end{array}$ & $\begin{array}{c}1.3112 \\
(1.3112)\end{array}$ & $\begin{array}{c}8.075,53 \\
(\mathbf{8} .075,53)\end{array}$ \\
\hline Balkan Investment Bank & $\begin{array}{c}0.28 \% \\
(0.30 \%)\end{array}$ & $\begin{array}{c}0.03 \% \\
(0.47 \%)\end{array}$ & $\begin{array}{c}5.11 \% \\
(5.35 \%)\end{array}$ & $\begin{array}{c}0.9608 \\
(1.0669)\end{array}$ & $\begin{array}{c}261,60 \\
(2.693,59)\end{array}$ \\
\hline Privredna banka & $\begin{array}{c}6.68 \% \\
(7.18 \%)\end{array}$ & $\begin{array}{c}1.57 \% \\
(1.95 \%)\end{array}$ & $\begin{array}{c}2.29 \% \\
(4.46 \%)\end{array}$ & $\begin{array}{c}1.2348 \\
(1.3351)\end{array}$ & $\begin{array}{c}6.542,02 \\
(9.288,89)\end{array}$ \\
\hline Bor Banka & $\begin{array}{c}2.23 \% \\
(8.70 \%)\end{array}$ & $\begin{array}{c}0.81 \% \\
(1.81 \%)\end{array}$ & $\begin{array}{c}3.74 \% \\
(4.03 \%)\end{array}$ & $\begin{array}{c}1.1997 \\
(1.2867)\end{array}$ & $\begin{array}{c}9.433,99 \\
(10.117,29)\end{array}$ \\
\hline I.K banka Zenica & $\begin{array}{c}3.70 \% \\
(9.71 \%)\end{array}$ & $\begin{array}{c}1.04 \% \\
(1.12 \%)\end{array}$ & $\begin{array}{c}4.13 \% \\
(3.45 \%)\end{array}$ & $\begin{array}{c}1.2014 \\
(1.2116)\end{array}$ & $\begin{array}{c}5.145,32 \\
(11.520,64)\end{array}$ \\
\hline Volksbank BH & $\begin{array}{c}4.17 \% \\
(5.50 \%)\end{array}$ & $\begin{array}{c}0.47 \% \\
(1.97 \%)\end{array}$ & $\begin{array}{c}3.42 \% \\
(4.60 \%)\end{array}$ & $\begin{array}{c}1.1121 \\
(1.3101)\end{array}$ & $\begin{array}{c}5.700,84 \\
(\mathbf{8 . 1 2 4 , 3 8 )}\end{array}$ \\
\hline Intesa San Paolo & $\begin{array}{c}3.26 \% \\
(5.61 \%)\end{array}$ & $\begin{array}{c}0.34 \% \\
(1.94 \%)\end{array}$ & $\begin{array}{c}3.51 \% \\
(4.57 \%)\end{array}$ & $\begin{array}{c}1.0723 \\
(1.3070)\end{array}$ & $\begin{array}{c}3996.89 \\
(8259.39)\end{array}$ \\
\hline Raiffeisen Bank & $\begin{array}{c}2.61 \% \\
(5.67 \%)\end{array}$ & $\begin{array}{c}0.23 \% \\
(1.93 \%)\end{array}$ & $\begin{array}{c}2.86 \% \\
(4.56 \%)\end{array}$ & $\begin{array}{c}1.0523 \\
(1.3054)\end{array}$ & $\begin{array}{c}2934.84 \\
(8327.12)\end{array}$ \\
\hline Komercijalna Banka & $\begin{array}{c}1.05 \% \\
(5.78 \%)\end{array}$ & $\begin{array}{c}0.10 \% \\
(1.90 \%)\end{array}$ & $\begin{array}{c}3.28 \% \\
(4.53 \%)\end{array}$ & $\begin{array}{c}1.0114 \\
(1.3025)\end{array}$ & $\begin{array}{c}870.81 \\
(8460.30)\end{array}$ \\
\hline Unicredit Bank B.L & $\begin{array}{c}3.35 \% \\
(4.04 \%)\end{array}$ & $\begin{array}{c}0.38 \% \\
(1.50 \%)\end{array}$ & $\begin{array}{c}4.02 \% \\
(4.85 \%)\end{array}$ & $\begin{array}{c}0.9277 \\
(1.2305)\end{array}$ & $\begin{array}{c}2,386.74 \\
(6,347.35)\end{array}$ \\
\hline Bobar Banka & $\begin{array}{c}4.13 \% \\
(5.03 \%)\end{array}$ & $\begin{array}{c}0.53 \% \\
(1.90 \%)\end{array}$ & $\begin{array}{c}3.81 \% \\
(4.65 \%)\end{array}$ & $\begin{array}{c}1.0677 \\
(1.3013)\end{array}$ & $\begin{array}{c}3,021.05 \\
(7,821.29)\end{array}$ \\
\hline Volksbank B.L & $\begin{array}{c}5.40 \% \\
(6.61 \%)\end{array}$ & $\begin{array}{c}0.82 \% \\
(1.92 \%)\end{array}$ & $\begin{array}{c}3.60 \% \\
(4.41 \%)\end{array}$ & $\begin{array}{c}0.9945 \\
(1.3024)\end{array}$ & $\begin{array}{c}6,875.12 \\
(8,805.57)\end{array}$ \\
\hline Нуро B.L & $\begin{array}{c}3.41 \% \\
(7.85 \%)\end{array}$ & $\begin{array}{c}0.30 \% \\
(2.20 \%)\end{array}$ & $\begin{array}{c}3.67 \% \\
(5.46 \%)\end{array}$ & $\begin{array}{c}1.0413 \\
(1.6034)\end{array}$ & $\begin{array}{c}4,706.20 \\
(11,305.78)\end{array}$ \\
\hline NLB & $\begin{array}{c}3.67 \% \\
(5.09 \%)\end{array}$ & $\begin{array}{c}0.28 \% \\
(1.86 \%)\end{array}$ & $\begin{array}{c}3.16 \% \\
(4.67 \%)\end{array}$ & $\begin{array}{c}1.0539 \\
(1.2905)\end{array}$ & $\begin{array}{c}2,513.26 \\
(7,632.90)\end{array}$ \\
\hline Union Banka & $\begin{array}{c}1.35 \% \\
(6.06 \%)\end{array}$ & $\begin{array}{c}0.42 \% \\
(1.83 \%)\end{array}$ & $\begin{array}{c}2.89 \% \\
(4.46 \%)\end{array}$ & $\begin{array}{c}1.0518 \\
(1.2948)\end{array}$ & $\begin{array}{c}1,791.01 \\
(8,788.84)\end{array}$ \\
\hline Pavlović International & $\begin{array}{c}0.96 \% \\
(1.47 \%)\end{array}$ & $\begin{array}{c}0.16 \% \\
(1.45 \%)\end{array}$ & $\begin{array}{c}3.73 \% \\
(4.84 \%)\end{array}$ & $\begin{array}{c}0.9728 \\
(1.2616)\end{array}$ & $\begin{array}{c}564.76 \\
(6,469.41)\end{array}$ \\
\hline Vakufska Banka & $\begin{array}{l}-2.46 \% \\
(2.19 \%)\end{array}$ & $\begin{array}{c}-0.63 \% \\
(1.31 \%)\end{array}$ & $\begin{array}{c}3.82 \% \\
(3.99 \%)\end{array}$ & $\begin{array}{c}0.8992 \\
(1.0609)\end{array}$ & $\begin{array}{c}-2,949.06 \\
(5,692.27)\end{array}$ \\
\hline Нуро & $\begin{array}{l}-11.35 \% \\
(0.32 \%)\end{array}$ & $\begin{array}{c}-0.92 \% \\
(1.30 \%)\end{array}$ & $\begin{array}{c}3.71 \% \\
(4.91 \%)\end{array}$ & $\begin{array}{c}0.8441 \\
(1.2472)\end{array}$ & $\begin{array}{c}-17,600.60 \\
(6,004.70)\end{array}$ \\
\hline NLB Razvojna & $\begin{array}{c}8.61 \% \\
(16.39 \%)\end{array}$ & $\begin{array}{c}0.62 \% \\
(1.58 \%)\end{array}$ & $\begin{array}{c}2.41 \% \\
(4.15 \%)\end{array}$ & $\begin{array}{c}0.8506 \\
(1.5907)\end{array}$ & $\begin{array}{r}7,036.28 \\
(17,788.05)\end{array}$ \\
\hline Sparkasse & $\begin{array}{l}-8.14 \% \\
(3.02 \%)\end{array}$ & $\begin{array}{l}-0.98 \% \\
(1.66 \%)\end{array}$ & $\begin{array}{c}3.14 \% \\
(4.75 \%)\end{array}$ & $\begin{array}{c}0.8459 \\
(1.2809)\end{array}$ & $\begin{array}{c}-7,779.92 \\
(7,095.15)\end{array}$ \\
\hline
\end{tabular}




\begin{tabular}{lccccc}
\hline Moja Banka & $-47.57 \%$ & $-5.95 \%$ & $3.36 \%$ & 0.4726 & $-28,871.20$ \\
& $(6.87 \%)$ & $(1.62 \%)$ & $(4.24 \%)$ & $(1.2727)$ & $(9,747.76)$ \\
MF Banka & $-32.05 \%$ & $-17.43 \%$ & $2.07 \%$ & 0.1340 & $-76,148.40$ \\
& $(\mathbf{6 . 5 5 \% )}$ & $\mathbf{( 1 . 7 0 \% )}$ & $\mathbf{( 4 . 3 3 \% )}$ & $\mathbf{( 1 . 2 8 1 4 )}$ & $\mathbf{( 9 , 3 7 1 . 2 9 )}$ \\
\hline
\end{tabular}

Source: Author's calculations

Appendix 6

Feasible targets 2010

\begin{tabular}{|c|c|c|c|c|c|}
\hline 2010 & $R O E$ & $R O A$ & NIM & $1 / E F F$ & $P / L$ \\
\hline NLB Razvojna & $\begin{array}{c}12.22 \% \\
(12.22 \%)\end{array}$ & $\begin{array}{c}1.04 \% \\
(1.04 \%)\end{array}$ & $\begin{array}{c}3.09 \% \\
(3.09 \%)\end{array}$ & $\begin{array}{c}1.6145 \\
(1.6145)\end{array}$ & $\begin{array}{c}10,981.88 \\
(10,981.88)\end{array}$ \\
\hline Bor Banka & $\begin{array}{c}3.68 \% \\
(3.68 \%)\end{array}$ & $\begin{array}{l}1.05 \% \\
(1.05 \%)\end{array}$ & $\begin{array}{c}3.35 \% \\
(3.35 \%)\end{array}$ & $\begin{array}{c}1.3221 \\
(1.3221)\end{array}$ & $\begin{array}{c}14,911.37 \\
(14,911.37)\end{array}$ \\
\hline UniCredit Bank & $\begin{array}{c}10.79 \% \\
(10.79 \%)\end{array}$ & $\begin{array}{c}1.02 \% \\
(1.02 \%)\end{array}$ & $\begin{array}{c}3.54 \% \\
(3.54 \%)\end{array}$ & $\begin{array}{c}1.2120 \\
(1.2120)\end{array}$ & $\begin{array}{c}13,745.78 \\
(13,745.78)\end{array}$ \\
\hline MF Banka & $\begin{array}{c}4.16 \% \\
(4.16 \%)\end{array}$ & $\begin{array}{c}2.64 \% \\
(2.64 \%)\end{array}$ & $\begin{array}{c}0.91 \% \\
(0.91 \%)\end{array}$ & $\begin{array}{c}0.4508 \\
(\mathbf{0 . 4 5 0 8 )}\end{array}$ & $\begin{array}{c}12,058.16 \\
(12,058.16)\end{array}$ \\
\hline Pavlović International & $\begin{array}{c}6.74 \% \\
(6.74 \%)\end{array}$ & $\begin{array}{c}1.13 \% \\
(1.13 \%)\end{array}$ & $\begin{array}{c}4.05 \% \\
(4.05 \%)\end{array}$ & $\begin{array}{c}1.0795 \\
(1.0795)\end{array}$ & $\begin{array}{c}4,396.72 \\
(4,396.72)\end{array}$ \\
\hline KIB Velika Kladusa & $\begin{array}{c}4.58 \% \\
(4.58 \%)\end{array}$ & $\begin{array}{c}1.51 \% \\
(1.51 \%)\end{array}$ & $\begin{array}{c}2.53 \% \\
(2.53 \%)\end{array}$ & $\begin{array}{c}1.2811 \\
(1.2811)\end{array}$ & $\begin{array}{c}6,860.58 \\
(6,860.58)\end{array}$ \\
\hline ProCredit Bank & $\begin{array}{c}-21.13 \% \\
(-21.13 \%)\end{array}$ & $\begin{array}{c}-2.15 \% \\
(-2.15 \%)\end{array}$ & $\begin{array}{c}5.43 \% \\
(5.43 \%)\end{array}$ & $\begin{array}{c}0.8008 \\
(0.8008)\end{array}$ & $\begin{array}{c}-6,712.21 \\
(-6,712.21)\end{array}$ \\
\hline Unicredit Bank B.L & $\begin{array}{c}1.55 \% \\
(1.55 \%)\end{array}$ & $\begin{array}{c}0.19 \% \\
(0.19 \%)\end{array}$ & $\begin{array}{c}4.46 \% \\
(4.46 \%)\end{array}$ & $\begin{array}{c}0.9654 \\
(\mathbf{0 . 9 6 5 4 )}\end{array}$ & $\begin{array}{c}1,167.93 \\
(1,167.93)\end{array}$ \\
\hline Volksbank B.L & $\begin{array}{c}8.33 \% \\
(8.33 \%)\end{array}$ & $\begin{array}{c}1.22 \% \\
(1.22 \%)\end{array}$ & $\begin{array}{c}4.00 \% \\
(4.00 \%)\end{array}$ & $\begin{array}{c}1.2706 \\
(1.2706)\end{array}$ & $\begin{array}{c}11,562.56 \\
(11,562.56)\end{array}$ \\
\hline I.K banka Zenica & $\begin{array}{c}4.22 \% \\
(4.22 \%)\end{array}$ & $\begin{array}{l}1.16 \% \\
(1.16 \%)\end{array}$ & $\begin{array}{l}3.63 \% \\
(3.63 \%)\end{array}$ & $\begin{array}{c}1.2592 \\
(1.2592)\end{array}$ & $\begin{array}{c}5,963.25 \\
(5,963.25)\end{array}$ \\
\hline Nova Banka & $\begin{array}{c}11.43 \% \\
(11.43 \%)\end{array}$ & $\begin{array}{l}1.18 \% \\
(1.18 \%)\end{array}$ & $\begin{array}{c}2.78 \% \\
(2.78 \%)\end{array}$ & $\begin{array}{l}1.1223 \\
(1.1223)\end{array}$ & $\begin{array}{c}12,231.68 \\
(12,231.68)\end{array}$ \\
\hline Bobar Banka & $\begin{array}{c}4.00 \% \\
(6.39 \%)\end{array}$ & $\begin{array}{c}0.60 \% \\
(0.92 \%)\end{array}$ & $\begin{array}{c}4.16 \% \\
(5.15 \%)\end{array}$ & $\begin{array}{c}1.0558 \\
(1.3690)\end{array}$ & $\begin{array}{c}3,743.85 \\
(6,995.47)\end{array}$ \\
\hline Turkish Ziraat & $\begin{array}{c}0.76 \% \\
(4.25 \%)\end{array}$ & $\begin{array}{c}0.30 \% \\
(0.60 \%)\end{array}$ & $\begin{array}{c}4.06 \% \\
(5.05 \%)\end{array}$ & $\begin{array}{c}1.0437 \\
(1.2878)\end{array}$ & $\begin{array}{c}1,765.69 \\
(6,093.16)\end{array}$ \\
\hline Intesa San Paolo & $\begin{array}{c}5.37 \% \\
(5.79 \%)\end{array}$ & $\begin{array}{c}0.54 \% \\
(0.76 \%)\end{array}$ & $\begin{array}{c}3.78 \% \\
(4.08 \%)\end{array}$ & $\begin{array}{c}1.1107 \\
(1.1963)\end{array}$ & $\begin{array}{c}6,840.98 \\
(7,368.64)\end{array}$ \\
\hline Sparkasse & $\begin{array}{c}2.39 \% \\
(3.65 \%)\end{array}$ & $\begin{array}{c}0.25 \% \\
(0.36 \%)\end{array}$ & $\begin{array}{c}3.82 \% \\
(4.13 \%)\end{array}$ & $\begin{array}{c}1.0449 \\
(1.1370)\end{array}$ & $\begin{array}{c}2,338.06 \\
(3,877.04)\end{array}$ \\
\hline Vakufska Banka & $\begin{array}{c}0.53 \% \\
(0.58 \%)\end{array}$ & $\begin{array}{c}0.12 \% \\
(0.31 \%)\end{array}$ & $\begin{array}{c}3.97 \% \\
(4.39 \%)\end{array}$ & $\begin{array}{c}1.0212 \\
(1.1283)\end{array}$ & $\begin{array}{c}605.73 \\
(6,169.02)\end{array}$ \\
\hline Komercijalna Banka & $\begin{array}{c}0.83 \% \\
(3.62 \%)\end{array}$ & $\begin{array}{c}0.22 \% \\
(0.46 \%)\end{array}$ & $\begin{array}{c}3.72 \% \\
(4.15 \%)\end{array}$ & $\begin{array}{c}1.0281 \\
(1.1658)\end{array}$ & $\begin{array}{c}2,077.66 \\
(5,735.70)\end{array}$ \\
\hline Raiffeisen Bank & $\begin{array}{c}2.12 \% \\
(2.46 \%)\end{array}$ & $\begin{array}{c}0.21 \% \\
(0.49 \%)\end{array}$ & $\begin{array}{c}3.64 \% \\
(4.22 \%)\end{array}$ & $\begin{array}{c}1.0381 \\
(1.2032)\end{array}$ & $\begin{array}{c}2,470.87 \\
(7,639.73)\end{array}$ \\
\hline Volksbank BH & $\begin{array}{c}1.71 \% \\
(2.05 \%)\end{array}$ & $\begin{array}{c}0.19 \% \\
(0.32 \%)\end{array}$ & $\begin{array}{c}3.42 \% \\
(4.10 \%)\end{array}$ & $\begin{array}{c}1.0419 \\
(1.2507)\end{array}$ & $\begin{array}{c}2,401.56 \\
(6,815.75)\end{array}$ \\
\hline Privredna banka & $\begin{array}{c}3.95 \% \\
(8.20 \%)\end{array}$ & $\begin{array}{c}0.69 \% \\
(1.12 \%)\end{array}$ & $\begin{array}{c}2.92 \% \\
(3.55 \%)\end{array}$ & $\begin{array}{c}1.1024 \\
(1.3637)\end{array}$ & $\begin{array}{c}3,596.07 \\
(8,695.32)\end{array}$ \\
\hline NLB & $\begin{array}{c}1.03 \% \\
(5.29 \%)\end{array}$ & $\begin{array}{c}0.07 \% \\
(0.40 \%)\end{array}$ & $\begin{array}{c}3.05 \% \\
(3.68 \%)\end{array}$ & $\begin{array}{c}1.0135 \\
(1.2473)\end{array}$ & $\begin{array}{c}708.70 \\
(5,441.18)\end{array}$ \\
\hline Balkan Investment Bank & $\begin{array}{c}3.00 \% \\
(8.79 \%)\end{array}$ & $\begin{array}{c}0.46 \% \\
(1.00 \%)\end{array}$ & $\begin{array}{c}2.84 \% \\
(3.74 \%)\end{array}$ & $\begin{array}{c}0.9944 \\
(1.3398)\end{array}$ & $\begin{array}{c}2,902.79 \\
(9,969.96)\end{array}$ \\
\hline Union Banka & $\begin{array}{c}2.91 \% \\
(10.52 \%)\end{array}$ & $\begin{array}{c}0.81 \% \\
(1.13 \%)\end{array}$ & $\begin{array}{c}2.27 \% \\
(3.17 \%)\end{array}$ & $\begin{array}{c}1.0823 \\
(1.5104)\end{array}$ & $\begin{array}{r}3,851.79 \\
(10,524.32)\end{array}$ \\
\hline Hypo B.L & $\begin{array}{l}-21.47 \% \\
(8.16 \%)\end{array}$ & $\begin{array}{l}-3.00 \% \\
(0.65 \%)\end{array}$ & $\begin{array}{c}3.47 \% \\
(3.38 \%)\end{array}$ & $\begin{array}{c}0.6067 \\
(1.5153)\end{array}$ & $\begin{array}{r}-44,925.20 \\
(\mathbf{8}, \mathbf{8 2 3 . 2 0})\end{array}$ \\
\hline Moja Banka & $\begin{array}{l}-35.42 \% \\
(7.15 \%)\end{array}$ & $\begin{array}{l}-5.67 \% \\
(0.60 \%)\end{array}$ & $\begin{array}{c}2.69 \% \\
(3.58 \%)\end{array}$ & $\begin{array}{c}0.4794 \\
(1.3532)\end{array}$ & $\begin{array}{r}-29,080.20 \\
(9,607.41)\end{array}$ \\
\hline Нуро & $\begin{array}{c}-93.63 \% \\
(10.72 \%)\end{array}$ & $\begin{array}{l}-7.47 \% \\
(0.92 \%)\end{array}$ & $\begin{array}{c}3.19 \% \\
(3.28 \%)\end{array}$ & $\begin{array}{c}0.4020 \\
(1.4945)\end{array}$ & $\begin{array}{r}-118,861.00 \\
(10,981.81)\end{array}$ \\
\hline
\end{tabular}

Source: Author's calculations 


\section{About the authors}

Deni Memić, PhD is a lecturer at Sarajevo School of Science and Technolocy, Economics Department teaching Accounting. For the last six years has been working for Hypo Alpe Adria Bank d.d. Mostar, currently holding a position of Director of Retial Risk Management Department. He is a licensed investment advisor, a stockbroker and dealer. He is also engaged as an expert consultant at Memić Consulting d.o.o. Sarajevo. His fields of expertise include banking, financial management, risk management, technical and fundamental analysis, accounting. Author can be contacted at deni.memic@ssst.edu.ba or deni.memic@hypo-alpe-adria.com

Selma Škaljić-Memić, MSc graduated at School of Economics and Business, University of Sarajevo in 2009. In 2012 she obtained MSc degree also at School of Economics and Business in Sarajevo in cooperation with Griffith College, Dublin and Nottingham Trent University. Selma's work experience encompasses employment with Sarajevo Canton Office of the Prosecutor, as the expert officer in the Finance and Accounting Department; Bilans (accounting, auditing and consulting company), as an accountant; and Central Bank of Bosnia nad Herzegovina, as the expert officer in the Department of Acounting and Finance. Author can be contacted at selma.skaljic@hotmail.com 